\title{
Zapad-2017 anatomija: kai kurie Rusijos karinio planavimo ypatumai"*
}

Visi po SSSR žlugimo vykę Zapad mokymai (1999, 2009, 2013 ir 2017 metais) pritraukdavo kaimyninių valstybių dèmesị ir iššaukdavo skirtingus vertinimus. Kiekvieną kartą jų metu vykdavo kažkas tokio, ką Vakarų valstybėms buvo sunku suprasti ir paaiškinti. Palaipsniui, vertinant tiek Zapad mokymus, tiek Rusijoje ir jos ginkluotose pajègose vykstančius pasikeitimus, buvo surinkta pakankamai informacijos ir ịrodymų, leidžiančių dalinai paaiškinti Rusijos pajègų veiksmų skirtingu Zapad metu niuansus bei priežastis, kodèl taip buvo elgiamasi.

Galima teigti, kad, skirtingai nuo NATO ir daugumos Vakarų valstybių, Rusijos kariškiai kitaip planuoja ir vykdo savo karinę veiklą. Tai paaiškinama carinès ir Sovietų Rusijos karinio elito prisirišimu prie Prūsijos Generalinio Štabo (GŠ) tradicijų ir filosofijos, propaguojančių savo metodus, leidžiančių šalies vadovams efektyviai valdyti ir panaudoti karinę valstybès sudedamąją. Dabartinès Rusijos kariškiai linkę pasilikti prie šių tradicijų, laikydami, kad šiandienos technologijos progresas leidžia jei ne pašalinti, tai bent jau smarkiai sumažinti neigiamas planavimo, paremto Prūsijos GŠ filosofija, puses ir taip pat sustiprinti jo efektyvumą. Rusijoje detalus išankstinis operacijų planavimas, paremtas vykdomų veiksmų sinchronizacija, pajęgų pasirengimas atlikti joms numatytas užduotis ir vadovybių geba jiems vadovauti ir kontroliuoti daro Rusijos karinius pajègumus efektyviu šalies kariavimo ir užsienio politikos ịrankiu.

Zapad mokymai parodè, kad jų metu tikrinama potencialaus karo su stipriu priešininku Vakaruose koncepcija („Zapad operacija“) ir jos planas. Ir koncepcija, ir planas yra paremti atitinkamomis prielaidomis, o jų esmę sudaro detaliai iš anksto suplanuoti, labai koordinuoti karinių pajegu veiksmai laike ir erdveje. Visas karas apimtų tris etapus. Nuo 1999 m. visa tai Zapad mokymų metu buvo tikrinama: iš pradžiu atskirus elementus ir etapus, o per Zapad 2017 kompleksiškai ir patikrinant visus tris Zapad operacijos etapus.

Verta pastebetti, kad bent jau porą kartų (2009 ir 2017 metais) Zapad mokymai atliko ne tik pajègų pasirengimo testavimą, bet ir karinès maskuotés bei strateginio komunikavimo Vakarams vaidmenị. Panašu, kad abiem atvejais tai daugiau ar mažiau pasisekè.

\footnotetext{
* Ats. mjr. Daivis Petraitis - Krašto apsaugos ministerijos Tarptautinių ryšių ir operacijų departamento direktoriaus pavaduotojas. Adresas korespondencijai: Totorių g. 25/3, 01121 Vilnius, tel. (8 5) 278 5237, el.p.petraitisd@yahoo.com.

${ }^{* *}$ Studija parengta Generolo Jono Žemaičio Lietuvos karo akademijos užsakymu. 2017 m. lapkričio 13 d. autorinè sutartis Nr. 8P-7.

*** Šioje studijoje pateikti vertinimai ir mintys yra be išimčių tik autoriaus ir niekada negali būti vertinami kaip Lietuvos Respublikos krašto apsaugos ministerijos ir jos padalinių oficiali pozicija.
} 


\section{Ivadas}

Rusijos kariškiai laikosi principo, kad bet kokios karinès operacijos sèkmės laidas yra ne tik karių ir karinių vienetų parengimas apskritai, bet ir rengimasis kiekvienai operacijai konkrečiai. Tą geriausiai iliustruoja istorija apie rusų karvedį A. Suvorovą, kuris, siekdamas sustiprinti savo posakị „sunku pratybose - lengva mūšyje“, rengdamasis šturmuoti Izmailo tvirtovę, nurodè pastatyti jos maketą ir treniruojantis visus veiksmus atlikti kaip įmanoma realiau.

Ilgainiui susiklostė taip, kad Rusijos kariškiai perėmė daug prūsiškų kariavimo tradicijų. Nemažai pastangų dèta ir Prūsijos Generalinio štabo, ypatingą dèmesị skyrusio karinių operacijų planavimo kokybei, principų diegimui carinès, Sovietų Sajungos ir dabartinès Rusijos karyboje.

Karininkai rengti carinès, Sovietų Sąjungos bei Rusijos Federacijos Generalinio štabo (toliau - GŠ) akademijose, buvo ir yra mokomi, kad karinių operacijų sèkmès laidas yra gerai suplanuoti, visa apimantys, sinchronizuoti pagal laiką ir erdvę kariniai veiksmai ir pajègos, parengtos tiksliai ir laiku vykdyti joms tuose planuose numatytas užduotis. Jei tikètume pastaruoju metu pasirodžiusiais daugelio aukšto rango Rusijos kariškių atsiminimais, Sovietų Sąjungos Generalinio štabo parengti karo su NATO planai buvo detalūs, sinchronizuoti pagal laiką ir erdvę. Paties štabo karininkai buvo laikomi to metu karinio vadovavimo ir valdymo sistemos elitu ir turejo teisę ne tik patarti vadams, bet, esant būtinybei, kontroliuoti plano vykdymą, duoti įsakymus jo vardu. ${ }^{1}$ Iš pajègų buvo tikimasi tinkamai igyvendinti tuos planus.

Tradicijos ir patirtis išliko, todèl, panašu, kad $2013 \mathrm{~m}$. sausị prezidento Putino pasirašytas pirmasis Rusijos Federacijos gynybos planas (2013-2015 $\mathrm{m})^{2}$ ir $2015 \mathrm{~m}$. lapkriti atnaujintas jo variantas (2016-2020 m.) taip pat yra detalūs ir numatantys visų valstybės pajègumų (ịskaitant ir karinius) veiksmus planai. Savo esme jie labai primena tai, kas NATO terminijoje vadinama Patvirtintu gynybos planu (PGP) (angl. Standing Defence Plan - SDP). Skirtingu šaltinių teigimu, Rusijos Federacijos 2016-2020 m. gynybos planas susideda iš daugelio situacinių planų. Jame numatytas virš penkiasdešimties ịvairių ministerijų, žinybų ir institucijų dalyvavimas. Ir vienas iš tokių patvirtintų planų, tikriausiai, skirtas karui su technologiškai stipriu oponentu Vakaruose.

Nuo 1999 m. Rusijoje vykusių Zapad mokymų (ypač Zapad-09 ir Zapad-13) veiksmų analizė leidžia teigti, kad jų metu tikrintas Rusijos planas,

\footnotetext{
${ }^{1}$ The Soviet General Staff: A command structure for military planing and operations, CŽV, Gegužè, 1982, išslaptinta 2010 m. gegužès 4 d. (CIA-RDP83T00233R000100170002-4).

${ }^{2}$ TV žinios RTR „Vesti“, 19.00, 2013-01-29.
} 
kaip kariauti su lygiaverčiu ir stipresniu priešu Vakaruose. Šia studija pabandysiu ịvertinti, kaip Rusija kariautų tokị karą. Visa potencialaus karo su Vakarais (NATO) kampanija studijoje bus ịvardijama kaip „Zapad operacija“. Panašu, kad joje panaudota didelè dalis Šaltojo karo laikų kariavimo principų, kurie modifikuoti, atsižvelgiant ị tai, kad pasikeite tiek Rusijos kariniai pajègumai, t. y. Rusija nebeturi buvusios SSSR karinès galios, tiek ir geopolitiné aplinka - Vakarai kovos ne su komunistine, bet su kapitalistine, nacionaline valstybe.

Generalinio štabo vyriausioji operacinè valdyba (rus. Главное оперативное управление ГШ ВС РФ) buvo pagrindinè struktūra, kurianti „Zapad operacijos" koncepciją ir jos igyvendinimo planą. Generalinis štabas (kitos jo valdybos) buvo ịtrauktos ị karinių (ir kitų) pajègumų, reikalingų jai igyvendinti, sukūrimą ${ }^{3}$. Taigi „Zapad operacija“ yra GŠ produktas ir smarkiai susieta su armijos generolu J. Balujevskiu. Jam būnant Rusijos Generalinio štabo operacinès valdybos viršininku (1997-2001), parengtas teorinis šios operacijos (karo) planas. Pastarasis patikrintas Zapad-99 metu, o vèliau, generolui tapus pirmuoju Generalinio štabo viršininko pavaduotoju (2001-2004) ir Generalinio štabo viršininku (2004-2008), darbas buvo tęsiamas. Tiesa, kadangi pats „Zapad operacijos" planas jau buvo, dabar reikejjo sukurti pajėgas, kurios visa tai galèjo igyvendinti mūšio lauke. Taigi, Generalinis štabas susikoncentravo ị Rusijos karinès reformos, kuri turèjo sukurti pajègas įvykdyti tokias operacijas, vykdymą. Parengtas ir patvirtintas vykdymo planas numate iš esmès naujų karinių pajègų sukūrimą, o pats reformos procesas buvo suskirstytas ị etapus ir turejjo trukti daugiau nei dešimtmetị ${ }^{4}$. Pirmasis jos etapas, baigtas $2015 \mathrm{~m}$., sukūrè realias pajègas ${ }^{5}$, leidusias patvirtinti jau minètą pirmąji Rusijos Federacijos gynybos planą.

Atliekant studiją, daugiausia remtasi oficialiais Rusijos gynybos ministerijos ir informacinių agentūrų pranešimais, neklasifikuotais Rusijos kariniais norminiais dokumentais ir mokomąja medžiaga bei rusiška analitine informacija (konferencijos, interviu, pranešimai, video ir t. t.). Taip pat naudotasi neslapta ir išslaptinta užsienio valstybių analitine medžiaga. Surinkta informacija leido parengti „Zapad operacijos“ aprašymą ir įvertinti, kaip ji buvo testuojama skirtingų Zapad mokymų metu.

Beveik neabejotina, kad konflikto su Vakarais atveju, Rusijos sąjungi-

\footnotetext{
${ }^{3}$ The Soviet General Staff: A command structure for military planing and operations, CŽV, Gegužè, 1982, išslaptinta $2010 \mathrm{~m}$. gegužès $4 \mathrm{~d}$. (CIA-RDP83T00233R000100170002-4)

${ }^{4}$ D. Petraitis, „Rusijos ginkluotųjų pajègų reforma 2005-2015 m.“, „Lietuvos metinė strateginè apžvalga“, 2010-2011, t. 9., p. 159-190.

${ }^{5}$ D. Petraitis, „Naujasis karinis Rusijos veidas“, „Lietuvos metinė strateginė apžvalga“, 2014-2015, t. 13., p. $97-120$.
} 
ninkai bus ịtraukti, tačiau studijoje įvertinti tik Rusijos pajęgu veiksmai. Tai padaryta sąmoningai. Rusijos „Zapad operacija“ - tai karas, kai nesitikima pereiti $\mathfrak{i}$ visuotini susinaikinimą. Visuotinio branduolinio karo variantas yra numatytas, tačiau Rusijai netikslingas maksimalus operacijos/konflikto išplètimas. Nors Rusijos-Baltarusijos karinè jungtinè grupuotè dalyvauja Zapad mokymuose ir neabejotinai turi jai skirtus tikslus „Zapad operacijoje“, tačiau bent jau karinių veiksmų pradžioje bus remiamasi tik Rusijos pajejgumais. Ir ne visais. Nors visų Zapad mokymų metu lygiagrečiai vyko aktyvi karinè veikla ir kitose Rusijos karinèse apygardose (jungtinèse strateginėse vadovybėse, JSV), tačiau nèra pakankamai duomenų teigti, kad šių pajègų mokymai buvo „Zapad operacijos" dalis. Kitu JSV pajègos gali būti panaudojamas (ir treniruojamos) kaip „Zapad operacijos“ pajęgų sustiprinimas ar rezervas, bet, kaip minejjau, konflikto išplètimas šiuo atveju apsunkintų jo sèkmingą užbaigimą.

\section{Zapad tipo operacija. Kaip ji suplanuota ir vykdoma}

Ivertinus surinktą informaciją ir iki šiol vykusių Zapad mokymų metu Rusijos ir jos sajungininkų karių vykdytus veiksmus, galima teigti, kad „Zapad operacija " turètų būti vykdoma trimis etapais. Pirmasis - staigus netikètas oponento užpuolimas, placdarmų ir teritorijų užgrobimas ir įsitvirtinimas. Jis galètų trukti nuo vienos iki kelių savaičių. Antrasis - pasiekto rezultato užtvirtinimas ir sèkmès išplètimas, konflikto stabilizavimas/stabdymas. Pastarasis galètų trukti 1-3 mèn. Ir trečiasis - plataus masto (visos valstybès) gynyba, pasitelkiant visus valstybès pajègumus, pralaimèjimo atveju pereinanti ị visuotinị branduolinị karą. Visa „Zapad operacija " galètų trukti iki metų, pirmieji du etapai - 4-6 mèn.

Po pirmojo ir antrojo etapų planuojama daryti pauzes, kurių metu karinių veiksmų intensyvumas sumažètų. Panašu, kad tokie „atokveipiai“ turi du tikslus. Visų pirma, jie naudojami kitam etapui pajégoms sukaupti/sustiprinti. Antra, pabandyti įtikinti oponentą pereiti prie tolesnio konflikto sprendimo nekarinėmis priemonèmis. Rusijos kariškiai remiasi prielaida, kad nacionalinis Vakarų valstybių politinis elitas vertins konfliktą ne kaip Šaltojo karo laikų ideologinę priešpriešą, kurios metu SSSR tikslas buvo pakeisti Vakarų socialinę santvarką, bet kaip paprastą kapitalistinès valstybès kovą už savo interesus. Todèl Vakarai gali būti suinteresuoti derètis su Rusija tam, kad išvengtų konflikto eskalacijos ị visuotinị branduolinį karą. Panašu, kad Vakarų elgesys po Gruzijos ir Krymo dalinai šią prielaidą Rusijoje dar labiau pateisino. Kad būtų ịtikinama, ypač svarbu kiekvieną iš etapų užbaigti, jị kontroliuojant ir kylančioje trajektorijoje. Taip oponentui sudaromas papildomas psichologinis 
spaudimas, kad, neišnaudojus progos pereiti ị derybas, tolesni rezultatai bus tik Rusijos naudai.

Ivertinus Zapad mokymų metu karinių dalinių vykdytą veiklą, galima teigti, kad „Zapad operacija“ bus vykdoma, laikantis iš anksto suplanuotu veiksmų, o vienas iš mokymų tikslų yra patikrinti politinès ir karinès vadovybės gebą, laikantis plano vadovauti pajègoms ir kontroliuoti konfliktą, o pajègoms efektyviai veikti pagal parengtus planus ir/ar gaunamas komandas.

Detalaus plano tikrinimas turi savo specifiką. Jame kone pagrindinị vaidmeni vaidina veiksmu sinchronizacija, kuri yra apibrèžta laiko ir erdvès parametrais, todèl toks planas gali būti vertinamas tik testuojant jị taip, kad šie parametrai būtų minimaliai iškreipti, t. y. vykdant ilgalaikius mokymus didelèse teritorijose. Juos „suspaudus“ $i$ trumpalaikius ribotoje erdvejje vykdomus mokymus, bus patikrinta ne veiksmų sinchronizacija, bet atskirų plane numatytų veikejų geba atlikti jiems skirtas užduotis.

Taigi, patikrinti konkrečios operacijos planą trumpalaikių mokymų metu yra sunku (jei išvis įmanoma). Pirmiausia, tai reikštų didelị pratybų dalyvių skaičių, nes treniruoti reikètų visiems etapams numatytas pajègas. Tai neabejotinai iššauktų aplinkinių valstybių susirūpinimą. Be to, galiausiai būtų patikrinta tik operacijos dalyviu geba vykdyti veiksmus. Kaip minèta, trumpalaikès pratybos neleidžia patikrinti to, kas yra žymiai svarbiau - skirtingų vienetų ir štabų gebos veikti sinchroniškai ir reaguoti i gaunamus pakeitimus/ informaciją, o politinei-karinei vadovybei kontroliuoti operaciją visą jos vykdymo laiką. Tai galima padaryti tik rengiant pratybas, kurios trunka praktiškai tiek pat, kiek galètu trukti pati operacija.

Nei viena Vakarų valstybè sau tokio „malonumo“ leisti negali, pirmiausia, todèl, kad, pasibaigus Šaltajam karui, NATO ir praktiškai visos valstybès atsisakė SDP ir daugeliu atvejų turi vadinamuosius Preliminarius operacijų planus - POP (ang. Contingency operation plan COP). Pastarieji yra aptakūs ir numato tik bendrus veiksmus ir pajègų veikimo principus. Pavojaus atveju, pagal POP rengiamas konkretus operacijos planas. Taigi, Vakaruose surengti ilgalaikes pratybas reikštų suformuoti mokymų štabą, kuris pagal POP parengtų pratybų metu tikrinamą PGP. Vèliau sukurti atitinkamą pratybų vadovavimo-valdymo (V2) sistemą (angl. Command and Control C2) ir, galų gale, ịtraukti i mokymus PGP numatytus štabus ir pajegas. Dauguma to, kas aukščiau minèta, taikos metu net neegzistuoja ir turètų būti sukurta ar mobilizuota.

Rusijoje situacija kita. 2014 m. gruodžio 1 d. sukurtas Nacionalinis gynybos valdymo centras (NGVC) (angl. National Defense Management Centre NDMC) yra nuolat veikianti sudetine Generalinio štabo, atsakingo už Rusijos 
Federacijos Gynybos plano igyvendinimą, dalis. Taigi, NGVC tuo pat metu yra tas mokymų štabas, kuris gali patikrinti „Zapad operacijos“ planą. Nuolat veikiantis V2 ir jo išplètimas iki vadovavimo-valdymo-ryšių (V2R) sistemos (angl. Command, Control, Communication, C3) kuriamas dabar vykstančios karinès reformos rèmuose. Taigi, struktūra ir V2R pagrindas ilgalaikèms pratyboms yra, jo kurti ar mobilizuoti nereikia. Reikalus komplikuoja kita problema - oficialiai paskelbtos ir vykdomos ilgalaikès karinès pratybos gali ne tik atskleisti patvirtinto plano esmę, bet ir iššaukti visų dėmesị ir, tikriausiai, susirūpinimą. Kad to būtų išvengta, pasitelkiama Rusijos patirtis ir polinkis ị maskuotę ir slaptumą.

Kad pratybos būtų pilnavertės ir neiššauktų nereikalingo dèmesio, rengiant Zapad mokymus, imamasi atitinkamų maskuotès priemonių. Idealiausiai, žinoma, būtų juos tęsti tiek laiko, kiek truktų pati „Zapad operacija“, bet tada, kaip minèta, potencialus oponentas galètų perprasti plano detales. Pasirinktas sprendimas - pratybos ilgalaikès, tačiau paslèptos po kita karine veikla. Paskelbus pasirengimo Zapad pradžią (paprastai prieš 4-6 mèn. iki oficialių Zapad mokymų), po pasirengimo priedanga tikrinami atskiri operacijos elementai. Jie „ištirpsta“ kitoje karinių dalinių veikloje arba užmaskuojami kaip planinè jų veikla. Toks išskaidymas leidžia patikrinti tai, ko negalima patikrinti per trumpalaikius mokymus, t. y. kariniu vienetu geba sinchronizuoti veiksmus pagal laiką ir vietas, $o$ štabų - ivvertinti ir kontroliuoti suplanuotą sinchronizaciją.

Kaip jau minèta, viena iš esminių sąlygų, leidžiančių patikrinti sinchronizaciją per laiką, yra visaapimančio (tiek skirtinguose lygiuose, tiek skirtingose teritorijose) V2R tinklo sukūrimas. Rusijoje jis kuriamas stacionariu (rus. стационарные пункты управления) ir lauko valdymo (rus. полевые пункты управления) punktų pagrindu ir leidžia keistis informacija bei perduoti komandas nuo taktinio iki strateginio lygmens imtinai. Už tokio tinklo sukūrimą atsakinga GŠ Vyriausioji ryšiu valdyba (rus. Главное управление связи $)^{6}$, jo funkcionavimą užtikrina karinio ryšio ir valdymo vienetai ${ }^{7}$.

Laikantis mokymų išskaidymo per laiką praktikos, oficialūs mokymai, iš esmès, tampa daugiau demonstracinio-propagandinio pobūdžio renginiu, skirtu vidaus ir užsienio auditorijai, o ne realiu pajègų ir štabų treniravimu. Sprendžiant pagal akcentus, pademonstruotus jau ivvykusių Zapad mokymų metu, oficialiai skelbtu „Zapad“ mokymu (trunkančiu apie savaite) metu rodoma tik operacijos dalis ar jos elementas, kurie naudingi Rusijai, priklausomai nuo tuo metu esančios saugumo situacijos. Taigi, oficialūs Zapad mokymai tam-

\footnotetext{
${ }^{6}$ Rusijos GM internetinis puslapis: http://eng.mil.ru/en/structure ${ }^{7}$ JSV lygyje - ryšių (teritorinès) ir valdymo brigados ir kiti vienetai.
} 
pa daugiau ne mokymais, o vakarietiškų karinių mokymų garbių svečių dienos (angl. Distinguished Visitors Day - DVD) ekvivalentu.

Karinès reformos rezultatas - Rusija atsisakè teritorinio pajègų panaudojimo principo. Dabar jos pajègos privalo būti pasirengusios veikti visur, kur reikès, todèl dalis „Zapad operacijos“ elementų, tokių kaip pajègų perdislokavimas ar kovos veiksmai nepažistamose vietovèse, gali būti atliekami (ir yra atliekami) ir kituose (centriniuose, rytiniuose ir pan.) Rusijos regionuose ${ }^{8}$.

\section{Zapad mokymų analizè}

Grį̌̌kime prie jau ịvykusių Zapad. Po Zapad-81 pratybų ir SSSR subyrèjimo Zapad mokymai nebevyko. Rusija, atrodo, buvo linkusi ne konfrontuoti, o bendradarbiauti su NATO. Pasikeitimas prasidejo 1999 m., kai Rusija èmèsi keistų veiksmų, nukreiptų i konfrontaciją, ir dar daugiau - šios organizacijos reakcijos ị Rusijos veiksmus tikrinimo. 1999 m. birželio 11 d. oficialiai pasibaigè Kosovo karas. Rusija kartu su NATO turèjo pradèti bendrą taikos palaikymo operaciją, tačiau vietoj to jau kitą dieną (birželio 12 d.) ịvyko „garsusis“ Rusijos desantininkų žygis į Prištinos oro uostą. Desantininkų batalionas atliko netikètą kelių šimtų kilometrų žygi, užèmè Prištinos oro uostą, ėmė rengtis jo gynybai ir ruošti nusileidimo taką galimam pastiprinimui priimti. Atvykusių NATO karių ị oro uostą neįleido ir, sprendžiant pagal to meto vaizdo medžiagą, nelabai stengèsi paaiškinti, kas darosi. Tų dienų vaizdo įraše matosi, kad eiliniai rusų kariai nelabai suprato, kas dedasi, o tiesiog vykdè ịsakymus. Tai kas gi vyko? Po daugelio metų šiai operacijai vadovavęs Rusijos specialiụjų pajėgų majoras Yunus-bekas Bamatgireyevichius Yevkurovas prisipažino, kad atvykę desantininkai rado oro uostą jau kontroliuojamą rusų specialios paskirties pajėgų, kurios, jo žodžiais, ten buvo jau nuo gegužès mėnesio. Majoras turejjo vykdyti įsakymą, t. y. kartu su jais laikytis Prištinoje, tačiau net pats nežinojo, kodèl ir kiek ilgai ${ }^{9}$. Taigi, desantininkai tik vykdè parengtą planą. Panašu, kad tai buvo pirmasis Rusijos Generalinio štabo suplanuotos konfrontacijos su NATO ir NATO reakcijos ị tai patikrinimas. NATO atsitrauké, perejjo ì dialogą ir Rusijos kariai pasiliko Prištinoje. Tada GŠ žengè kitą patikrinimo žingsni - Zapad- $99^{10}$.

\footnotetext{
${ }^{8}$ D. Petraitis, „Rusijos ginkluotụjų pajègų reforma 2005-2015 m.“, „Lietuvos metinè strateginè apžvalga“, 2010-2011, t. 9., p. 159-190.

${ }_{9}^{9}$ Dok. Filmas „Генерал без биографии. Петр Ивашутин“, Russia.tv, https://russia.tv/video/show/brand_ $\mathrm{id} / 61426 / . . . \mathrm{id} / . . . / 1569986 /$.

${ }^{10}$ „Россия планирует брать Запад на испуг“, Kommersant, 1999-07-10.
} 


\subsection{Zapad-99}

Zapad-99 vyko tuo metu, kai Rusijos ginkluotụjų pajègų būklè neleido panaudoti pilnaverčių karinių dalinių poligonuose, todèl visi trys etapai (taip pat ir branduolinis) buvo GŠ suplanuoti ${ }^{11}$ ir štabuose "pražaisti “" iš esmès, teoriškai. Operacijos plane figūravo naujos karinès struktūros (Jungtinès strateginès vadovybès) ${ }^{12}$, kurios realybejje sukurtos buvo tik 2008 m., prasidejus reformai. Veiksmus laukuose imitavo nedidelès (kuopos dydžio) pajègos, atstovavusios atitinkamas karines apygardas ir laivynus, tačiau bendras dalyvių skaičius (iskaitant ir kitas institucijas) siekè 50 tūkstančių ${ }^{13}$. Lyginant su šia diena, per Zapad-99 buvo vienas esminis skirtumas - potencialiose atakos teritorijose (Baltijos valstybėse) nebuvo NATO. Tada kariškių sumanymas buvo patikrinti (ir pagąsdinti) NATO, kaip būtų elgiamasi Baltijos šalyse okupacijos metu. Daryta prielaida, kad NATO nedrịs veltis ị branduolinị karą, didelio masto valstybès gynybos Rusijoje tikriausiai neprireiks, o užteks tik staigiai užimti Baltijos valstybes, vieno ar dviejų prevencinių branduolinių smūgių ir vèliau ejusio pasiūlymo derètis.

Po Zapad-99 gana ilgai strateginio lygmens pratybos nebuvo vykdomos. Tada buvo paskelbta, kad kitos panašios pratybos vyks po dviejų metu. Jeigu laikytumės GŠ skelbiamos nuostatos, kad strateginio lygmens mokymai karinejje apygardoje vykdomi kas keturis metus, kitos Zapad pratybos turejjo ịvykti $2001 \mathrm{~m}$. arba $2003 \mathrm{~m}$. Jos neịvyko, kaip neịvyko ir $2007 \mathrm{~m}$. Tokią pauzę galima būtų paaiškinti paprastai - teorinis planas jau patikrintas, tačiau realių pajègų jam igyvendinti nèra. Šalis planavo ir rengèsi esminei ginkluotųjų pajègu reformai, tad laikotarpis iki oficialios karinès reformos Rusijoje pradžios (2008 m. spalio $15 \mathrm{~d}$.) buvo skirtas eksperimentavimui ir pasirengimui ${ }^{14}$. Be to, $2003 \mathrm{~m}$. jau buvo beveik aišku, kad Baltijos šalys bus pakviestos i NATO, o Rusija ir toliau neturejo pajègų, kurios būtų galejjusios Zapad-99 metu „pražaistą" operaciją igyvendinti. Neturejo jos tokių pajègų ir 2007 m., o 2008 m. pabaigoje, pradejjus karinę reformą Rusijoje, susiklostè kritinè situacija. Visos pajègos buvo masiškai išformuojamos ir performuojamos, tad Rusijos kariškių vertinimu, pajęgų, galinčiu užtikrinti šalies gynybą, beveik nebuvo. Reikèjo laiko jas sukurti. Kad būtų galima dalinai išspręsti susidariusią situaciją, 2009 m. ir buvo pravesti Zapad-09 mokymai.

\footnotetext{
11 „Утечка из военной разведки“, Завтра, 1999-07-06, http://zavtra.ru/blogs/1999-07-0614.

12 „Запад-99“, „Правда“, 24 июня 1999, https://www.pravda.ru/news/world/24-06-1999/903671-0/.

13 „Запад-99“, „Правда“, 24 июня 1999, https://www.pravda.ru/news/world/24-06-1999/903671-0/.

${ }^{14}$ D. Petraitis, „Reorganization of the Russian Armed Forces“, FNDU, Helsinki, 2012.
} 


\subsection{Zapad-09}

Zapad-09 buvo pirmieji mokymai po to, kai Rusija pradejo oficialiai paskelbtą karinę reformą. Kaip jau minèta, senosios pajegos buvo naikinamos, kariai masiškai atleidžiami, daliniai ir junginiai išformuojami, o nauji tik pradèti kurti. 2009 m. pavasarị Rusijoje tebuvo tik penkios naujo tipo brigados ${ }^{15}$, visa kita buvo išformuojama, performuojama ir t. t. Naujos konvencinès pajègos buvo tokios silpnos, kad nebūtų pajègusios atremti net silpniausio puolimo. Patvirtinto valstybès gynybos plano irgi nebuvo. Tokiomis sąlygomis Rusijos politiné-kariné vadovybė savo konvencinį silpnumą vertino kaip aplinkybę, kuria Vakarai (NATO) gali pasinaudoti. Pagrindinis Zapad-09 tikslas buvo ne naujai kuriamų pajėgų rengimas, bet Vakarų atgrasymas nuo pagundos, pasinaudojant Rusijos konvencinių pajėgų silpnumu ją užpulti. Nors turimi pajègumai leido surinkti deklaruotą mokymų dalyvių skaičių ${ }^{16}$, tačiau pagrindiniu oficialiu Zapad-09 mokymu akcentu tapo taktinio branduolinio ginklo panaudojimo treniruoté. Juose ypatingai akcentuotas „Zapad operacijos" antrasis etapas - konflikto stabdymas ir taktiniu branduoliniu ginklu. Zapad-09 metu atlikta taktinio branduolinio smūgio imitacija visuomenès informavimo priemonėse pavirto branduoline Varšuvos ataka. Atviruose rusiškuose šaltiniuose patikimos informacijos apie Varšuvą kaip atakos objektą rasti nepavyko, bet strateginès komunikacijos prasme rezultatas buvo pasiektas, Vakarams susikoncentravus i „Varšuvos ataką“, pradejjus svarstymus ir konsultacijas, Rusija laimèjo laiko, reikalingo naujų pajègų kūrimui ir stiprinimui. Taigi, tikslas atgrasymas ir laiko laimejjimas - buvo pasiektas.

Nežiūrint ị tai, 2009 m. „Zapad operacija“ buvo testuojama, prisilaikant anksščiau minètų principų: ištęsimo per laiką ir išplètimo geografiškai. Ji prasidejo žymiai anksčiau (liepos mèn.), kaip mokymai „Ruduo 2009“ (rus. „Осень-2009“), kurie be oficialių Zapad-09 apemè ir mokymus „Ladoga-09“ ir „Kaukazas-09“. Apie tai tuo metu atvirai kalbejo Rusijos kariné politinè vadovybè, o tuometinis Rusijos sausumos pajegų vadas generolas leitenantas S. Skokovas netgi davè interviu žurnalistams ${ }^{17}$. Verta pastebėti, kad vèliau $(2013 \mathrm{~m}$. ir 2017 m.) apie jokius „Rudens“ tipo mokymus jau net nebeužsimenama.

Pirmojo „Zapad operacijos“ etapo - staigaus užpuolimo ir užgrobimo veiksmai Zapad-09 mokymų metu vykdyti skirtinguose poligonuose epizodiškai

\footnotetext{
${ }^{15}$ Г. Миранович, А. Худолееи, А. Земляниченко, „Бригады набирают силу“, Красная Звезда, 2010-02-17.

${ }^{16}$ Oficialiai apie 12,5 tūkst. karių, apie 700 tankų ir šarvuočių, 250 artilerijos sistemų, 100 orlaivių. 17 „Активная фаза учений „Запад-2009“ пройдет на полигоне в Беларуси“, Москва, РИА Новости, 2009-09-29, https://ria.ru/defense_safety/20090929/186789728.html.
} 
tiek atvirai, tiek ir paslèptai. Imituojančiomis pajėgomis laukuose buvo pajègos iki bataliono dydžio. Trečiojo „Zapad operacijos“ etapo (masinès gynybos) veiksmai Zapad-09 metu beveik nevykdyti. Tuo metu visuotinès gynybos koncepcijos ir jos elementų (pvz., naujos mobilizacijos) dar nebuvo. Pagrindiné problema, neleidusi didinti pratybų masto, buvo praktiškai jokio V2R nebuvimas. Reformuotose Rusijos pajègose tiek V2, tiek V2R buvo labai prastos būklès. Tuometinis Rusijos prezidentas D. Medvedevas žurnalistams teigè, kad apie 85 proc. turimos V2R įrangos yra beviltiškai pasenusi ir nepanaudojama ${ }^{18}$.

\subsection{Zapad-13}

Oficialūs Zapad-13 vyko, kai Rusijos ginkluotosios pajègos jau buvo reformuotos, pagrindinè jų dalis suformuota, o prie gynybos ministerijos vairo stojo armijos generolas Sergejus Šoigu, jau tada pagarsèjęs savo organizaciniais gabumais. Reformuotų ginkluotų pajegu atsiradimas leido patvirtinti pirmajji naujosios Rusijos istorijoje Gynybos planą ${ }^{19}$, kuriame konvencinis komponentas jau turèjo savo vietą ir užduotis. $2012 \mathrm{~m}$. spali pratestuota Rusijos branduolinè triada ${ }^{20}$ garantavo strategini atgrasymą. Patys Zapad-13 mokymai vykdyti „Zapad operacijos“ planui patikrinti, todèl jų trukmė buvo žymiai ilgesnè nei oficialiai skelbta. Turimi pajėgumai leido tikrinti konflikto stabilizavimą konvenciniais pajègumais, dèl ko tikrasis dalyvių skaičius viršijo oficialiai skelbtus skaičius $^{21}$.

Zapad-13 prasidèjo kovo mènesị (11-15 d.) strategine štabų ir centrinių karinio valdymo organų treniruote (rus. стратегическая командноштабная тренировка с иентральными органами военного управления и военными округами), kurios metu po oficialiai skelbiamu pasirengimo mokymams priemonių aptarimu, tikriausiai, buvo aptarti atskiri operacijos etapai, konkrečios užduotys pajègoms ir laikas, kada tai atlikti ${ }^{22}$.

Kaip jau minèta, panašu, kad oficialiu Zapad-13 rugsèji metu buvo akcentuojamas antrasis "Zapad operacijos" etapas, t. y. konflikto stabdymas ir sé$k m e$ išpletimas konvenciniais pajègumais. Dauguma šio etapo veiksmų vyko oficialių Zapad-13 pratybų poligonuose ir už jų ribų (pvz., mokymai Šiaurès

\footnotetext{
${ }^{18}$ А. Гаварский, „Связь решает все“, Красная Звезда, 2010-05-22.

${ }^{19}$ Pirmasis Rusijos gynybos planas 2013-2015 m. patvirtintas $2013 \mathrm{~m}$. sausio $24 \mathrm{~d}$.

${ }^{20}$ Д. Андреев, „Триаду проверили на прочность“, Красная звезда, 2012-10-22.

${ }^{21}$ Oficialiai - apie 13 tūkst. karių, apie 350 tankų ir šarvuočių, 50 artilerijos sistemų, 50 orlaivių (lèktuvų ir sraigtasparnių). Po mokymų oficialiai - 25 tūkst. karių, apie 550 tankų ir šarvuočių, 100 orlaivių (lekktuvų ir sraigtasparnių), 10 laivų.

${ }^{22}$ РИА Новости, http://ria.ru/defense_safety/20130311/926661611.html\#ixzz2aVgigbul.
} 
laivyne rugsèjo 21-25 d. d. ${ }^{23}$; Baltijos laivyno mokymai). Kadangi konvencinès pajègos buvo pajegios užtikrinti joms numatytų užduočių ịvykdymą, prasmės demonstruoti (ir akcentuoti) taktinio branduolinio ginklo panaudojimą nebuvo ir branduolinis komponentas mokymuose atliko tik strateginio atgrasymo treniruotę.

Pirmojo „Zapad operacijos“ etapo - staigaus užpuolimo ir užgrobimo treniruotė vykdyta oro desanto kariuomenès pagrindu sukurtomis Greitojo reagavimo pajègomis (GRP). Ji vyko tiek atvirai oficialių Zapad-13 mokymų metu, tiek ir paslèpus šio etapo veiksmus po KSSO mokymais „Sąveika 2013“ (rus. „Взаимодействие-2013“) $)^{24}$. Vykdyti pirmojo etapo veiksmus treniruotasi ir keletą mènesių prieš oficialius Zapad-13 mokymus, tiesa, daugeliu atveju tai vykdyta nepilnais pajègumais (iki bataliono taktinès grupès) ${ }^{25}$. Viena iš priežasčių, neleidusių didinti masto, ir toliau išliko adekvataus V2R nebuvimas. Reformuotose Rusijos pajegose tiek V2, tiek V2R vis dar buvo prastos būklès. Nors tuo metu atskiros pajėgos (pvz., GRP) jau turejjo atnaujintas V2 ir netgi V2R, leidusias jiems komunikuoti su aukštesniais ir žemesniais štabais ${ }^{26}$, tačiau centralizuoti ir visa apimantys V2 ir V2R buvo dar tik kuriami ${ }^{27}$.

Trečiasis etapas - plataus masto (visos valstybės) gynyba, pasitelkiant visos valstybės pajègumus - testuotas, ịtraukiant kitas valstybės pajėgas (VRM, YSM) bei bandant ịvykdyti, matyt, nesèkmingai ${ }^{28}$, rezervo dalinių mobilizaciją.

\subsection{Zapad-17}

Zapad-17 vyko tuo metu, kai ginkluotosios pajegos buvo beveik baigtos reformuoti, atnaujintas Rusijos Gynybos planas ${ }^{29}$, ịvesta kontrakto kariu sistema, pajègų perginklavimas ir t. t. Visa tai dar labiau sustiprino strategini atgrasymą ir leido testuoti pasirengimą "Zapad operacijos" pirmajam ir antrajam etapams dar didesniu mastu. Dalis atskirų šios operacijos etapų ir juose numatytų taktinių pajègų veikimo elementų buvo atlikti kituose iki Zapad-17 vykusiuose mokymuose, tokiuose kaip Vostok-14; Centr-15; Kavkaz-16. Pa-

\footnotetext{
${ }^{23}$ Dalyvavo virš 2,5 tūkst. karių, 30 laivų, 50 šarvuočių, 20 orlaivių.

${ }^{24}$ Mokymai „Vzaimodeistvija 2013“ vyko 2013 m. rugsèji.

${ }^{25}$ Bendri Rusijos-Baltarusijos mokymai Brestkij poligone 2013 m. balandžio 22-24 d. vykdyti batalionų dydžio pajègumais.

${ }^{26}$ Pavyzdžiu gali būti Greitojo reagavimo pajègų „Andromeda D“ sistema.

${ }^{27}$ D. Petraitis, „A new Face of Russian military“, Lithuanian Annual strategic review, 2014-2015, Vol 13.

${ }^{28}$ Po Zapad-2013 mokymų atstatydintas GŠ mobilizacijos valdybos viršininkas gen. plk. V. Smirnovas.

${ }^{29}$ Atnaujintas Rusijos gynybos planas 2016-2020 m. patvirtintas 2015 m. lapkričio mèn.
} 
vyzdžiui, mokymuose Vostok-14 tikrintas strateginis perdislokavimas ${ }^{30}$, Centr-15 ir Kavkaz-16 metu tikrinta nauja elektroninès kovos forma - elektroninis smūgis ir informacinis teritorijos blokavimas (rus. радиоэлектронный удар и инбормационное блокирование местности ${ }^{31}$ ), naujas puolimo elementas - masinis aviacijos smūgis ${ }^{32}{ }^{33}$, testuotas informacinès kovos organizavimas ${ }^{34}$, teritorinè gynyba ${ }^{35}$, sąveika su kitomis šalies jègos struktūromis ${ }^{36} \mathrm{ir}$ t. t.

Labai svarbus pasiekimas, leidęs 2017 m. pakelti „Zapad operacijos“ testavimą ị kokybiškai aukštesnị lygi, buvo naujos V2R sistemos atsiradimas. Čia turima galvoje ne tik automatizuota mūšio valdymo sistema (AMVS) „Andromedos D“. Kitų pajègų AMVS sistemų progresas ir naujų ryšio organizavimo priemonių (Antey ${ }^{37}$ ir pan.) įdiegimas leido užtikrinti patikimą ir saugų ryšs tarp štabų, esančių tūkstančių kilometrų atstumu vienas nuo kito ${ }^{38}$. Nuo $2016 \mathrm{~m}$. naujų ryšių priemonių ir automatizuotų mūšio valdymo sistemų tiekimas ị pajègas suintensyvejo ${ }^{39}{ }^{40}$, o nuo $2017 \mathrm{~m}$. pradžios pagrindiniai tiekimai buvo nukreipti i Vakarų karinès apygardos ryšių ir valdymo vienetus ${ }^{41}{ }^{42}$.

Šio potencialo užteko, kad modernios ryšio priemonès ir naujos AMVS būtų ne tik stacionariuose, bet ir lauko (mobiliuose) valdymo punktuose. Pastarieji po ryšių pajègų stovyklų organizavimo priedanga išskleidžiami

\footnotetext{
${ }^{30}$ „Военных с Запада России перебросили авиацией на Дальний Восток для участия в стратегическом командно-штабном учении“, Интерфакс-АВН, Москва 2014-09-19.

31 „Новые формы и способы ведения радиоэлектронной борьбы (РЭБ), будут применены в ходе учения „Центр-2015“, Минобороны России, Москва, РИА Новостиб 20158-09-15.

${ }^{32}$ А. Пинчук, „Массированным ударом“, Красная звезда, 2015-10-01.

33 „ВС на учениях „Кавказ-2016“ отработали авиаудар и борьбу с ракетами“, Москва, РИА Новости, 2016- 09-14.

${ }^{34}$ На учениях „Кавказ-2016“ впервые отработали „информационное противоборство“, Москва, РИА Новости, 2016-09-14.

${ }_{35}$ Р. Голованов, „На «Кавказе» артиллерия и истребители разгромили противника“, Kompravda, 2016-09-08, http://www.kompravda.eu/daily/26579.4/3594518/

36 „На учениях „Кавказ-2016“ отработали взаимодействие российских силовиков“, Полигон Опук (Крым), РИА Новости, 2016-09-09.

37 „Русская армия начала эксплуатацию системы новейшей связи „Антей“, Radioslovo, 2017-05-23, http://radioslovo.ru/russkaya-armiya-nachala-ekspluataciyu-sistemy-novejshej-svyazi-antej/.

${ }^{38}$ В. Сирык, „Суперуниверсальный «Антей»: чем уникален радиоцентр для высшего руководства армии“, Zvezda, 2017-05-20, https://tvzvezda.ru/news/opk/content/201705200800-o5d9.htm.

39 „Концерн „Созвездие“ поставил Минобороны первые комплексы „Антей“, Интерфакс-АВН, 2017-05-15.

40 „Войска связи 3 ВО в 2016 году получат 2,5 тысячи единиц новой техники“, Москва, РИА Новости, 2016-01-02, http://ria.ru/defense_safety/20160102/1353298275.html\#ixzz3wFoIDOlV. 41 „В войска Западного военного округа (ЗВО) поступили унифицированные командно-штабные машины (УКШМ) Р-149MA1“, Пресс-служба Западного военного округа, http://function.mil.ru/ news_page/country/more.htm?id=12130927@egNews.

${ }^{42}$ И. Мугинов, „Войска связи ЗВО в 2016 году получат 2,5 тысячи единиц новой техники“, РИА Новости, 2016-01-02, http://ria.ru/defense_safety/20160102/1353298275.html\#ixzz3wFoIDOlV
} 
kiekvieno „Zapad operacijos“ etapo metu ${ }^{43} 444^{46}$. Taip užsitikrinama, kad kiekvienas mokymuose dalyvaujantis karinis vienetas nuolat turètų ryšį ir galètų būti valdomas. Orientuojantis ị perspektyvą, mokymų metu 1-oje tankų armijoje buvo aktyvuotas naujas eksperimentinis valdymo punktas ${ }^{47}$.

Visgi svarbiausia, kad Generalinis štabas per Nacionalinị gynybos valdymo centrą (NGVC) sukoncentravo savo rankose visą V2R sistemos kontrolę. Be to, centras jau turèjo didžiulius kompiuterių resursus, leidžiančius modeliuoti ir įvertinti visas susiklosčiusias situacijas ${ }^{48}$.

Ir vèl mokymai ištęsti per laiką. Zapad-17 prasidèjo sauș JSV „Vakarai“vadovybès operatyvine-mobilizacine sueiga (rus. оперативно-мобилизационные сборь), kurioje dalyvavo arti dviejų šimtų vadų ir štabų karininkų ${ }^{49}$. Joje, matyt, pristatyti „Zapad operacijos" terminai, demonstruoti nauji taktiniai elementai (taktinis desantas) ${ }^{50}$, nurodyta, kad po pasirengimo Zapad-17 priedanga apygardos pajègos praves virš dviejų tūkstančiu skirtingo lygio mokymų ${ }^{51}$. Po kelių dienų ginkluotųjų pajègų vadų operatyvinès-mobilizacinès sueigos metu apie „Zapad operacijos" pradžią informuojami kitų JSV vadai, karinio valdymo organų (NGVC) vadovai, operacinių vadovybių (OV) vadai ir štabų viršininkai. Joje, tikriausiai, irgi pristatyti „Zapad operacijos" terminai, demonstruoti nauji JSV darbo elementai, Rusijos grupuotess Sirijoje veiksmų analizè ir Rusijos Federacijos regiono Gynybos štabo veiksmai karo metu ir t. t. ${ }^{52}$.

Iki oficialių Zapad-17 mokymų pajegose po planinių ar pasiruošimo mokymams pratybu priedanga buvo atliktos pirmojo ir antrojo „Zapad ope-

\footnotetext{
${ }^{43}$ М. Севастьянов, „Учения ВДВ на северо-западном направлении: длинные руки русского десанта“, РИА Новости, 2017-07-07.

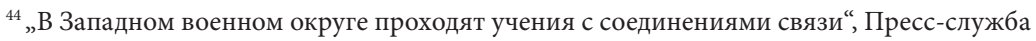

Западного военного округа, 2017-07-31, http://structure.mil.ru/structure/okruga/west/news/more. htm?id=12135740@egNews.

45 „Более 500 связистов Балтийского флота вышли на учение“, Пресс-служба Западного военного округа, 2017-08-15, www.mil.ru.

46 „На учении «Запад-2017» связисты ВДВ обеспечивают пункты управления связью на расстоянии до 2 тыс. Км“, 2017-09-16, www.mil.ru.

${ }^{47}$ Н. Сурков, А. Рамм, Е. Дмитриев, „Арматами» будет управлять «штаб звездных войн“, Известия, 2017-09-20.

${ }^{48}$ D. Petraitis, „Naujasis karinis Rusijos veidas“, „Lietuvos metinė strateginė apžvalga“, 2014-2015, t.13, p. 97-120.

${ }^{49}$ С. Пятаков, „Комсостав ЗВО начал подготовку к учениям „Запад-2017“, Москва, РИА Новости, 2017-01-10.

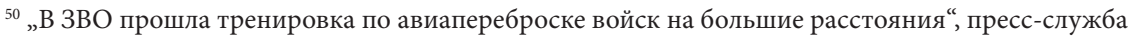
3ВО, Москва, РИА Новости, 2017-01-12.

51 „Военнослужащие ЗВО проведут более двух тысяч учений в ходе подготовки к стратегическому учению „Запад-2017“, пресс-службе округа, Москва, Интерфакс-АВН, 2017-01-17.

52 „Шойгу констатировал повышение профессионального уровня руководства ВС РФ“, Москва,

TACC, 2017-01-18.
} 
racijos" etapų treniruotès. Didžioji jų dalis vyko $2017 \mathrm{~m}$. liepos 3-7 d. ir rugpjūčio 4-19 d. Oficialiu Zapad-17 mokymu rugsèjo 14-20 d. akcentas - trečiasis etapas - plataus masto (visos valstybès) gynyba, pasitelkiant visos valstybès pajégumus, buvo dalinai skirtas pademonstruoti Vakarams Rusijos pasiryžimą imtis atsakomuju veiksmu karinio konflikto su ja atveju.

Zapad-17 mokymai savo esme nieko nesiskyrè nuo ankstesniųjų, tačiau buvo atlikti kokybiškai. Rusijos nuomone, pasikeitusi saugumo situacija reikalavo vèl panaudoti mokymus strateginei komunikacijai, t. y. akcentuoti jos pasirengimą gynybai. Pasibaigus agresyviems pirmojo ir antrojo "Zapad operacijos" etapams, Gynybos ministerija buvo suinteresuota pademonstruoti gynybinį etapą ir, deklaruojant atvirumą, pasikviesti žurnalistus ir kitų valstybių stebètojus stebèti oficialių Zapad-17 pratybų dalies.

\subsubsection{Zapad-17. „Zapad operacijos“ pirmasis etapas}

Paanalizuokime Zapad-17 mokymų eigą ir pabandykime suprasti, kas ten vyko. Eilè indikatorių leidžia teigti, kad 2017 m. liepos mèn. pirmoje pusèje (3-7 d.) ir praktiškai visą rugpjūtị (4-19 d.) dalis vykdytos karinés veiklos, dažnai ịvardintos kaip planinè, gali būti laikoma „Zapad operacijos“ pirmojo ir antrojo etapų treniruote. Konkretūs pajègų veiksmai, taktiniai elementai buvo atliekami ne tik dalinių mokymų poligonuose, bet ir specialaus rengimo (rus. специальная подготовка), vadovybès treniruočių (rus. командно-итабные тренировки) ir lauko stovyklų (rus. полевые сборы) metu. Abiejų laikotarpių metu buvo išskleisti mobilūs valdymo punktai ir sukurti ryšių kanalai. Panašu, kad visa apimantis V2 ir net V2R tinklas pirmajame etape rèmési Andromeda-D. Antrajame etape - jos ir JSV „Vakarai“ trijų ryšio brigadų ir kitų ryšių vienetų sukurta ir išlaikoma mobilių ir stacionarių valdymo punktų, aprūpintų nauja ryšių įranga, pagrindu sukurta V2R. Daugelio planinių pratybų temos ir laikai buvo akivaizdžiai koordinuoti ir atitiko konkretaus „Zapad operacijos“ etapo esmę, o pratybose dalyvavo pilnaverčiai kariniai pajègumai (bataliono taktinès grupès ir pan.). Pastarieji veikè, laikantis jungtinès operacijos principo, t. y. jų veiksmus rèmé aviacija, elektroninés kovos pajėgos, laivynas ir t. t.

Pirmojo "Zapad operacijos" etapo treniruote atlikta per oficialiai paskelbtas trijų strateginių štabų pratybas. Greitojo reagavimo pajegų, Vakarų JSV jungtinès grupuotės ir Vakarų karinès apygardos oro kosmoso gynybos 
štabų pratybos prasidejo beveik tuo pačiu metu. Liepos 3-4 $d .{ }^{53}$ per Greitojo reagavimo pajègų (Oro desanto) štabų treniruotę $e^{54} 98$-osios oro desanto (ODK) divizijos ir 31-osios ODK brigados vienetai skubiai palieka nuolatinès dislokacijos vietas ir pradeda pasirengimą operacijai: aktyvuoja V2R, rengiasi transportavimui/desantavimui ${ }^{55}$. Vakarų karinès apygardos oro-kosmoso gynybos pajègų štabų pratybose ${ }^{56}$ pajègos rengiasi atremti pirmąji atsaką (masinị oro smūgi), vykdo elektroninès kovos pratybas, skirtas „paslèpti“ savo pajègas, treniruoja oro gynybos sistemas $\mathrm{S} 400^{57}$. Vakarų JSV štabų pratybose treniruojamasi, kaip išvesti ir apsaugoti savo pajėgas nuo oponento atsakomojo smūgio ${ }^{59}$. Liepos $5 \mathrm{~d}$. prasideda puolimas. Jis pradedamas pagal šiuolaikinio karo kanonus - smūgiai didelio nuotolio tikslaus nutaikymo ginklais ị kritinę infrastruktūrą. Tai imitavo du strateginiai TU-95MS bombonešiai, kurie keturiomis ALCM X-101 sparnuotomis raketomis apšaudė už beveik 1000 km Sirijoje esančius sandèlius ${ }^{60}$ ir iš strateginio povandeninio laivo „Smolenskas“ Barenco jūroje paleista sparnuotoji raketa, nutaikyta ị už $400 \mathrm{~km}$ esantị „sudètingą jūrinị taikinị“61. Tikrovẻje tai galètų būti, pvz., laivų grupe uoste.

Tą pačią dieną Baltijos laivynas išplaukè i jūrą ${ }^{62}$. Laivai atlieka jūros atitvèrimo operacijas, oro gynybą, antvandeninių laivų kovą, išminavimą ir minavimą ${ }^{63}$, jūrų pèstininkų transportavimą ${ }^{64}$.

Visose numatytose užgrobti vietose suduodamas masyvus oro smūgis ${ }^{65}$,

\footnotetext{
${ }^{53}$ М. Севастьянов, „Учения ВДВ на северо-западном направлении: длинные руки русского десанта“, Полигон Струги Красные (Псковская область), РИА Новости, 2017-07-07.

${ }_{54}$ „Более 2 тыс. десантников перебросят в ходе учения к западным границам РФ“, Москва, Интерфакс-АВН, 2017-07-04.

55 „В Псковской области начинается активная фаза учений двух соединений ВДВ“, Москва, РИА Новости, 2017-07-05.

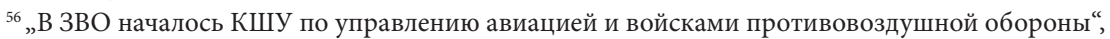
Минобороны России, 2017-07-03.

${ }^{57}$ „Москва Крылатые ракеты и ударные беспилотники „противника“ уничтожают авиация и расчёты ПВО в ходе учений на северо-западе РФ“, Интерфакс-АВН, 2017-07-03.

58 „Расчеты комплексов С-400 „Триумф“ отразили удар условного противника“, РИА Новости, Москва, 2017-07-06.

59 „Войска ЗВО в ходе учения нанесли массированный ракетно-авиационный удар по позициям условного противника“, Пресс-служба Западного военного округа, 2017-07-06, www.mil.ru.

${ }^{60}$ „Российские Ту-95МС нанесли ракетный удар по ИГ в Сирии“, Москва, ТАСС, 2017-07-05.

${ }_{61}$ „Атомная подлодка “Смоленск” в Баренцевом море поразила учебную цель крылатой ракетой “Гранит” на дальности 400 км - Минобороны РФ“, Москва, .Интерфакс-АВН, 2017-07-05.

62 „На Балтике начались учения ВМС“, Аргументы Недели, 2017-07-05.

63 „Тральная группа Балтийского флота провела учение по поиску и обезвреживанию мин“, Прессслужба Западного военного округа, 2017-07-06, www.mil.ru.

64 „На Балтийском флоте начинается активная фаза учения разнородных сил“, Пресс-служба Западного военного округа, 2017-07-05.

65 „Войска ЗВО в ходе учения нанесли массированный ракетно-авиационный удар по позициям условного противника“, Пресс-служба Западного военного округа, 2017-07-06, www.mil.ru.
} 
po kurio jas šturmuoja GRP vienetai. Oro smūgi imituoja Vakarų JSV karinès oro pajègos, kurios liepos $5 \mathrm{~d}$. Kaliningrado, Pskovo ir Leningrado sričių poligonuose surengia aviacijos antskrydžius ${ }^{66}{ }^{67}$. Greitojo reagavimo pajėgos, šiuo atveju 31-osios ODK brigados ir 98-osios ODK divizijos vienetai, pradeda puolimą, desantuodami karius ir techniką Staryje Strugi ir Kislovo poligonuose, užgrobia Staryje Strugi aerodromą, išmeta diversines grupes ił oponento užnugarį, o užgrobtuose placdarmuose organizuoja gynybą ${ }^{68}$.

Kaliningrade irgi nesnaudžiama. Baltijos laivyno aviacija suintensyvina veiksmus virš Baltijos jūros ir oro smūgiais sausumoje mažuose aukščiuose $e^{69}$ paremia 336-osios jūrų pesstininkų brigados Chmeliovkos poligone vykdomą jūros desantą ${ }^{70}$. Puolimas tęsiamas ir plečiamas. Pskove užgrobusios placdarmus, pajègos sulaukia pastiprinimo iš 76-osios ODK divizijos, kurios kariai liepos 6-7 d. orlaiviais ir sraigtasparniais atgabenami ir nusileidžia užgrobtame oro uoste (Staryje Strugi) ${ }^{71}$, o papildomos žvalgybinès diversinès grupès pasklinda priešo užnugaryje ir pradeda masinius diversinius veiksmus ${ }^{72}$. Kitų ODK vienetų kariai Pskovo srities poligonuose vykdo prasiveržimus ir reidus oponento užnugaryje, upių forsavimo ir pan. pratybas.

I puolimą įsijungia bendros paskirties pajègos. Sausumos pajègų žvalgybos padalinių pratybos (tema „Mūšiai miestuose ir puolimas mažomis grupėmis") vyksta Leningrado, Nižnij-Nivgorodo ir Maskvos poligonuose ${ }^{73}$. Po žvalgų eina pagrindinès pajegos. Šiuo atveju tai yra sausumos pajègų motošaulių ir tankų padaliniai, vykdantys pratybas Maskvos srityje. Jose treniruojamasi kovoti mieste, testuojamos naujos paramos ugnimi taktikos (tankų karuselè), atliekami koviniai reidai ir upių forsavimas, organizuojama sąveika su lekktuvais ir sraigtasparniais. Pratybose dalyvauja apie 1500 karių, 200 kovos

\footnotetext{
${ }_{66}$ „Авиация 3ВО отработала ракетно-бомбовый удар по войскам условного противника в Ленинградской области“, Пресс-служба Западного военного округа, 2017-07-06, www.mil.ru. ${ }^{67}$ http://structure.mil.ru/structure/okruga/west/news/more.htm?id=12132367@egNews.

68 „Под Псковом завершилась основная фаза учения соединений ВДВ“, Департамент информации и массовых коммуникаций Министерства обороны Российской Федерации, 2017-07-06, www.mil.ru. 69 „Летчики Балтфлота провели полеты над морем и бомбометание по полигону в Калининградской области“, Москва, Интерфакс-АВН, 2017-07-06.

70 „Около 600 военнослужащих и порядка 20 кораблей были задействованы в учении Балтфлота по высадке десанта в Калининградской области“, Москва. Интерфакс-АВН, 07072017.

${ }^{71}$ М. Севастьянов, „Учения ВДВ на северо-западном направлении: длинные руки русского десанта“, Полигон Струги Красные (Псковская область), РИА Новости, 2017-07-07.

72 „Две с половиной тысячи десантников проводят учение в Псковской области“, Псковская обл., Интерфакс-АВН, 2017-07-05.

${ }_{73}$ „Войсковые разведчики 3ВО отработают захват и уничтожение штабов и органов военного управления условного противника“, Пресс-служба Западного военного округа, 2017-07-08, www.mil.ru.
} 
technikos vienetų, orlaiviai SU34, sraigtasparniai Mi-8 ir Mi-2474. Kaliningrade veiksmus pradeda 11-ojo Armijos korpuso sausumos pajègų daliniai. 79-osios atskiros motošaulių brigados pratybose vykdomas puolimas, inžinerinè žvalgyba, veiksmai nežinomose teritorijoje. Jose dalyvauja apie 1500 karių, 200 kovos technikos vienetų.

Kadangi puolančios pajègos gali sutikti pasipriešinimą, puolimui remti ugnimi panaudojamos trumpo nuotolio raketos. Net trys (JSV) „Vakarai“

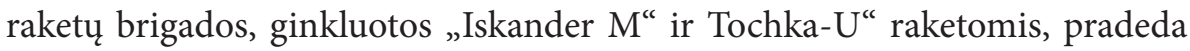
pratybas $^{75}$. Ketvirtoji raketų brigada (448-oji) atlieka kovinius šaudymus Kopustin Jar poligone, Astrachanej $\mathrm{e}^{76}$. Galimiems priešo kontrsmūgiams atremti oro gynybos pajėgos kartu su elektroninès kovos vienetais vykdo oponento masinio oro antskrydžio atrėmimo pratybas (S 400, EK „Krasucha“).

Apibendrinant šiuos veiksmus, pastebimas vienas ypatumas - visur vykdomas staigus puolimas, stipriai remiamas iš oro ir didelio nuotolio tikslaus nutaikymo ginklais ir apsaugomas oro gynybos ir kitomis priemonemis. Vien paminètuose veiksmuose (žr. 1 lentelę) galèjo dalyvauti daugiau nei 14 tūkst. karių, apie 1000 kovos technikos ir 3000 vnt. kitos karinès technikos ir įrangos, apie 70 orlaivių ir 20 laivų, o visi trijų štabų pratybų veiksmai buvo koordinuojami iš NGKC Andromeda-D ${ }^{77}$ ir kitų sistemų pagalba. Verta paminèti, kad tuo pat metu skirtingose Rusijos vietose vyko dar visa eilè mokymų, kurie galètų būti laikomi šio etapo treniruotès dalimi, tačiau tam reikètų papildomų ịrodymų ar informacijos.

1 lentelè. Zapad-17, tikètina, 1-asis etapas „Netikèta ataka/užpuolimas“

\begin{tabular}{|l|l|l|l|l|c|}
\hline $\begin{array}{l}\text { Data } \\
2017\end{array}$ & $\begin{array}{l}\text { Jungtiné } \\
\text { strateginè } \\
\text { vadovybé } \\
\text { JSV }\end{array}$ & Vienetai/Vieta & Dydis* & Veikla & Pastabos \\
\hline $\begin{array}{l}\text { Liepos } \\
\text { 3-5 d. }\end{array}$ & $\begin{array}{l}\text { JSV Greitojo } \\
\text { reagavimo } \\
\text { pajejgos }\end{array}$ & $\begin{array}{l}\text { Oro desanto 98-oji } \\
\text { ir 76-oji DD, 31-oji } \\
\text { brig. } \\
\text { Transporto aviacija, } \\
\text { Pskovas }\end{array}$ & $?$ & $\begin{array}{l}\text { Puolimas. Aliar- } \\
\text { mas, išėjimas iš } \\
\text { dislokacijos vietu, } \\
\text { pasiruošimas } \\
\text { desantavimui, V2 } \\
\text { aktyvavimas }\end{array}$ & $\begin{array}{l}\text { Oficialiai - ne } \\
\text { Zapad, veiksmu } \\
\text { sinchronizacija ir } \\
\text { pobūdis }\end{array}$ \\
\hline
\end{tabular}

\footnotetext{
74 „Российские военные под Нижним Новгородом учатся брать города с применением “танковой карусели”, Москва, Интерфакс-АВН, 2017-07-07.

${ }^{75}$ Пресс-служба Западного военного округа, 2017-07-05 (16.42), С расчетами «Искандер-М» и «Точка-У» 3ВО проведена тренировка по управлению ракетными ударами“, Интерфакс, 2017-07-08.

76 „Курские ракетчики провели учебно-боевые пуски ракет „Точка“ в Астраханской области“, Москва, Интерфакс-АВН, 2017-07-10.

77 „Учения ВДВ на северо-западном направлении: длинные руки русского десанта“, 2017-07-10, ttps://ria.ru/defense_safety/20170707/1498098871.html
} 


\begin{tabular}{|c|c|c|c|c|c|}
\hline $\begin{array}{l}\text { Liepos } \\
5 \mathrm{~d} \text {. }\end{array}$ & JSV „Šiaurè“ & $\begin{array}{l}\text { Povandeninès } \\
\text { Šiaurès laivyno } \\
\text { pajëgos } \\
\text { Barenco Jūra }\end{array}$ & $\begin{array}{l}+-100 \mathrm{~K} \\
1 \mathrm{PL}\end{array}$ & $\begin{array}{l}\text { Puolimas. Pov. laivas } \\
\text { „Smolensk“ šaudo } \\
\text { sparnuota raketa } \\
\text { "Granit“ i jūrinį taikini } \\
\text { už } 400 \text { km }\end{array}$ & $\begin{array}{c}\text { Oficialiai - ne } \\
\text { Zapad, veiksmų } \\
\text { sinchronizacija ir } \\
\text { pobūdis }\end{array}$ \\
\hline $\begin{array}{l}\text { Liepos } \\
5 \mathrm{~d} \text {. }\end{array}$ & $\begin{array}{l}\text { JSV } \\
\text { Branduolinès } \\
\text { pajègos }\end{array}$ & $\begin{array}{l}\text { Strateginès aviaci- } \\
\text { jos OV } \\
\text { Sirija }\end{array}$ & $\begin{array}{l}\text { ? K } \\
2 \text { Lek. }\end{array}$ & $\begin{array}{l}\text { Puolimas. } 2 \text { Tu } \\
\text { 95MSM strategi- } \\
\text { niai bombonešiai } \\
\text { paleidžia } 4 \text { spar- } \\
\text { nuotas raketas ALCM } \\
\text { X-101 i taikinius } \\
\text { Sirijoje }\end{array}$ & $\begin{array}{c}\text { Oficialiai - ne } \\
\text { Zapad, veiksmų } \\
\text { sinchronizacija ir } \\
\text { pobūdis }\end{array}$ \\
\hline $\begin{array}{l}\text { Liepos } \\
5 \mathrm{~d} \text {. }\end{array}$ & JSV „Vakarai“ & $\begin{array}{l}\text { Trys raketų briga- } \\
\text { dos } \\
\text { Maskvos, Len- } \\
\text { ingrado, Kursko } \\
\text { regionai }\end{array}$ & $\begin{array}{l}+-500 \mathrm{~K} \\
200 \mathrm{KT}\end{array}$ & $\begin{array}{l}\text { Puolimas. Raketų } \\
\text { smūgio koordinacija, } \\
\text { elektroniniai raketų } \\
\text { paleidimai }\end{array}$ & $\begin{array}{c}\text { Oficialiai - ne } \\
\text { Zapad, veiksmų } \\
\text { sinchronizacija ir } \\
\text { pobūdis }\end{array}$ \\
\hline $\begin{array}{l}\text { Liepos } \\
5 \mathrm{~d} \text {. }\end{array}$ & JSC „Vakarai“ & $\begin{array}{l}\mathrm{X} \text { ? ABC vienetas } \\
\text { Leningradas }\end{array}$ & $?$ & $\begin{array}{l}\text { Puolimas, gynyba. } \\
\text { Aerozolinè uždanga, } \\
\text { maskuojant „Is- } \\
\text { kander“ raketas }\end{array}$ & $\begin{array}{c}\text { Oficialiai - ne } \\
\text { Zapad veiksmų } \\
\text { sinchronizacija ir } \\
\text { pobūdis }\end{array}$ \\
\hline $\begin{array}{l}\text { Liepos } \\
6 \mathrm{~d} .\end{array}$ & JSV „Vakarai“ & $\begin{array}{l}\text { Oro gynybos } \\
\text { vienetai } \\
\text { Visoje Vakaru } \\
\text { karinèje apygardoje }\end{array}$ & $\begin{array}{l}+5000 \mathrm{~K} \\
+2000 \mathrm{KT}\end{array}$ & $\begin{array}{l}\text { Puolimas. Teritorijos } \\
\text { oro erdvès kontrolè/ } \\
\text { gynyba, oras-oras } \\
\text { mūšiai }\end{array}$ & $\begin{array}{c}\text { Oficialiai - ne } \\
\text { Zapad, veiksmų } \\
\text { sinchronizacija ir } \\
\text { pobūdis }\end{array}$ \\
\hline $\begin{array}{l}\text { Liepos } \\
6 \mathrm{~d} \text {. }\end{array}$ & JSV „Vakarai“ & $\begin{array}{l}\text { Elektroninès kovos } \\
\text { vienetai } \\
\text { Maskvos, Nižnij } \\
\text { Novgorod, Kalinin- } \\
\text { grado, Kursko sritys }\end{array}$ & $\begin{array}{l}+-150 \mathrm{~K} \\
20 \mathrm{KT}\end{array}$ & $\begin{array}{l}\text { Puolimas, gynyba. } \\
\text { Elektroninès kovos } \\
\text { priemonès apsau- } \\
\text { goti pajègas nuo oro } \\
\text { smūgio, ryšių trikdy- } \\
\text { mas ir žvalgyba }\end{array}$ & $\begin{array}{c}\text { Oficialiai - ne } \\
\text { Zapad, veiksmų } \\
\text { sinchronizacija ir } \\
\text { pobūdis }\end{array}$ \\
\hline $\begin{array}{l}\text { Liepos } \\
6 \mathrm{~d} \text {. }\end{array}$ & JSV „Vakarai“ & $\begin{array}{l}\text { 448-oji raketų } \\
\text { brigada } \\
\text { Astrachane }\end{array}$ & $\begin{array}{l}+-500 \mathrm{~K} \\
100 \mathrm{KT}\end{array}$ & $\begin{array}{l}\text { Puolimas. BR Točka } \\
\text { U paleidimas Kopus- } \\
\text { tin Jar poligone }\end{array}$ & $\begin{array}{c}\text { Oficialiai - ne } \\
\text { Zapad, veiksmų } \\
\text { sinchronizacija ir } \\
\text { pobūdis }\end{array}$ \\
\hline $\begin{array}{l}\text { Liepos } \\
5-7 \mathrm{~d} .\end{array}$ & $\begin{array}{l}\text { JSV Greitojo } \\
\text { reagavimo } \\
\text { pajėgos }\end{array}$ & $\begin{array}{l}\text { Oro desanto } \\
98-o j i, 76-o j i ~ D ., 31- \\
\text { oji D. brig. } \\
\text { Transporto aviacija } \\
\text { Pskovas }\end{array}$ & $\begin{array}{l}+-2500 \mathrm{~K} \\
500 \mathrm{KT} \\
40 \mathrm{Lek} . \\
\text { ir Sr. }\end{array}$ & $\begin{array}{l}\text { Puolimas. Aliarmas, } \\
\text { oro transportas, } \\
\text { oro šturmas, oro } \\
\text { ouosto užėmimas, } \\
\text { placdarmai, } \\
\text { sustiprinimas ore ir } \\
\text { žemėje, diversijos } \\
\text { priešo užnugaryje }\end{array}$ & $\begin{array}{c}\text { Oficialiai - ne } \\
\text { Zapad, veiksmų } \\
\text { sinchronizacija ir } \\
\text { pobūdis }\end{array}$ \\
\hline $\begin{array}{l}\text { Liepos } \\
6 \mathrm{~d} \text {. }\end{array}$ & $\begin{array}{l}\text { JSV Greitojo } \\
\text { reagavimo } \\
\text { pajègos }\end{array}$ & $\begin{array}{l}\text { 336-oji JBr. } \\
\text { Baltijos laivyno } \\
\text { aviacija } \\
\text { Kaliningrado sritis }\end{array}$ & $\begin{array}{l}+600 \mathrm{~K} \\
15 \mathrm{KT} \\
? \mathrm{O}\end{array}$ & $\begin{array}{l}\text { Puolimas. Placdarmo } \\
\text { užèmimas, jūru } \\
\text { desantas }\end{array}$ & $\begin{array}{c}\text { Oficialiai - ne } \\
\text { Zapad, veiksmų } \\
\text { sinchronizacija ir } \\
\text { pobūdis }\end{array}$ \\
\hline $\begin{array}{l}\text { Liepos } \\
6 \mathrm{~d} \text {. }\end{array}$ & $\begin{array}{l}\text { JSV Greitojo } \\
\text { reagavimo } \\
\text { pajègos } \\
\text { JSV „Vakarai“ }\end{array}$ & $\begin{array}{l}\text { Baltijos laivynas } \\
\text { Baltijos Jūra } \\
\text { Kaliningrado sritis }\end{array}$ & $\begin{array}{l}+1000 \mathrm{~K} \\
20 \mathrm{~L}\end{array}$ & $\begin{array}{l}\text { Puolimas, gy- } \\
\text { nyba. Minu užtvarų } \\
\text { šalinimas, desanto } \\
\text { laivų apsauga, minų } \\
\text { užtvaros, jūru } \\
\text { pėstininkų trans- } \\
\text { portavimas, jūrų } \\
\text { desantas }\end{array}$ & $\begin{array}{c}\text { Oficialiai - ne } \\
\text { Zapad, veiksmų } \\
\text { sinchronizacija ir } \\
\text { pobūdis }\end{array}$ \\
\hline
\end{tabular}




\begin{tabular}{|c|c|c|c|c|c|}
\hline $\begin{array}{l}\text { Liepos } \\
6 \mathrm{~d} .\end{array}$ & JSV „Vakarai“ & $\begin{array}{l}\text { Baltijos laivyno } \\
\text { aviacija } \\
\text { Kaliningrado sritis }\end{array}$ & $\begin{array}{l}\text { ? K } \\
10 \text { Lek. ir } \\
\text { Sr., }\end{array}$ & $\begin{array}{l}\text { Puolimas. Masyvus } \\
\text { oro smūgis prieš } \\
\text { puolimą, desanto } \\
\text { parama iš oro }\end{array}$ & $\begin{array}{c}\text { Oficialiai - ne } \\
\text { Zapad, veiksmų } \\
\text { sinchronizacija ir } \\
\text { pobūdis }\end{array}$ \\
\hline $\begin{array}{l}\text { Liepos } \\
6 \mathrm{~d} \text {. }\end{array}$ & JSV „Vakarai“ & $\begin{array}{l}\text { 6-oji Oro OV } \\
\text { Leningrado sritis }\end{array}$ & $\begin{array}{l}? \mathrm{~K} \\
10 ? \text { Lek. } \\
\text { ir Sr. }\end{array}$ & $\begin{array}{l}\text { Puolimas. Masyvus } \\
\text { oro smūgis prieš } \\
\text { puolimą, desanto } \\
\text { parama iš oro }\end{array}$ & $\begin{array}{c}\text { Oficialiai - ne } \\
\text { Zapad, veiksmų } \\
\text { sinchronizacija ir } \\
\text { pobūdis }\end{array}$ \\
\hline $\begin{array}{l}\text { Liepos } \\
6 \mathrm{~d} \text {. }\end{array}$ & JSV „Vakarai“ & $\begin{array}{l}\text { X? OV } \\
\text { X? MP } \\
\text { Nižnij Novgorodo } \\
\text { sritis }\end{array}$ & $\begin{array}{l}+-1300 \mathrm{~K} \\
250 \mathrm{KT} \\
10 ? \text { Lek. } \\
\text { ir Sr. }\end{array}$ & $\begin{array}{l}\text { Puolimas. Pulko } \\
\text { taktinè grupè puolant, } \\
\text { mūšis mieste, upès } \\
\text { forsavimas, „tankų } \\
\text { karuselë“ }\end{array}$ & $\begin{array}{c}\text { Oficialiai - ne } \\
\text { Zapad, veiksmų } \\
\text { sinchronizacija ir } \\
\text { pobūdis }\end{array}$ \\
\hline $\begin{array}{l}\text { Liepos } \\
6 \mathrm{~d} .\end{array}$ & JSV „Vakarai“ & $\begin{array}{l}\text { X? OV } \\
\text { Žvalgu vienetai } \\
\text { Nižnij Novgorodo, } \\
\text { Maskvos, Lenin- } \\
\text { grado sritys }\end{array}$ & $\begin{array}{l}+-1000 \mathrm{~K} \\
200 \mathrm{KT}\end{array}$ & $\begin{array}{l}\text { Puolimas. Mūšiai } \\
\text { mieste mažomis } \\
\text { grupémis, priešo } \\
\text { štabų atakos, objektų } \\
\text { užėmimas, ryšių } \\
\text { naikinimas }\end{array}$ & $\begin{array}{c}\text { Oficialiai - ne } \\
\text { Zapad, veiksmų } \\
\text { sinchronizacija ir } \\
\text { pobūdis }\end{array}$ \\
\hline $\begin{array}{l}\text { Liepos } \\
7 \mathrm{~d} \text {. }\end{array}$ & JSV „Vakarai“ & $\begin{array}{l}11 \text {-asis korpusas, } \\
X ? \text { motošaulių } \\
\text { vienetai } \\
\text { Kaliningrado sritis }\end{array}$ & $\begin{array}{l}+-1500 \mathrm{KS} \\
200 \mathrm{KT}\end{array}$ & $\begin{array}{l}\text { Puolimas. Veiksmai } \\
\text { puolant, koviniai } \\
\text { persidislokavimai, } \\
\text { objektų užèmimas }\end{array}$ & $\begin{array}{c}\text { Oficialiai - ne } \\
\text { Zapad, veiksmų } \\
\text { sinchronizacija ir } \\
\text { pobūdis }\end{array}$ \\
\hline $\begin{array}{l}\text { IŠ } \\
\text { VISO:* }\end{array}$ & & & $\begin{array}{l}\text {-+14000 K } \\
+-3600 \mathrm{KT} \\
-+70 \mathrm{O} \\
+-20 \mathrm{~L}\end{array}$ & & \\
\hline
\end{tabular}

${ }^{*}$ Visi skaičiai yra iš atvirų šaltiniu arba išskaičiuoti. I galima tų pačių karių dalyvavima skirtinguose veiksmuose atsižvelgta.

Legenda. JSV - jungtinė strateginė vadovybė, OV - operacinèvadovybė, brig. - brigada, MP - motošauliųpulkas, MD - motošaulių divizija, TD - tankų divizija, DD - orodesanto divizija,JBr. -jūrųpèstininkų brigada,KGbr.-krantųgynybosbrigada,K-kariai/jüreiviai,KT-karinètechnika(kovosirkt.),L-laivai: LA - antvandeniniai laivai, PL - povandeniniai laivai, KL - kiti laivai, O - orlaiviai, Lek. - lèktuvai, Sr. - sraigtasparniai.

\subsubsection{Zapad-17. „Zapad operacijos“ antrasis etapas}

Antrojo „Zapad operacijos“ etapo - pasiekto rezultato užtvirtinimas ir sèkmès išplètimas arba konflikto stabilizavimas - treniruote ịvyko rugpjūtị (7?23? d. d.). Visoje JSV „Vakarai“ teritorijoje prasidejo daug atrodytų visiškai nesusietų vieni su kitais greitojo reagavimo ir bendros paskirties pajègų dvišalių ir planinių mokymų. Rugpjūčio 13-14 d. visoje JSV „Vakarai“ teritorijoje prasidejjo apygardos ryšių pratybos ${ }^{78}$, kuriose dalyvavo JSV 1-oji valdymo, 132-oji teritorinès ryšių brigados ir 20-osios Operacinès vadovybès (OV) 9-oji ryšių brigados.

\footnotetext{
${ }_{78}$ „В ЗВО проведены тактико-специальные учения одновременно с тремя соединениями связи“, Пресс-служба Западного военного округа, 2017-08-07, www.mil.ru
} 
Iš viso - apie 4000 karių, 1000 technikos vienetų ${ }^{79}$. Prie jų prisijungè Baltijos laivyno ryšiu vienetai ${ }^{80}{ }^{81}$ ir ODK 38 -oji ODK ryšių brigada ${ }^{82}$. Per šias pratybas sukurtas realiai veikiantis, apie 50 mobilių ryšių punktų apimantis V2R tinklas ${ }^{83}$, apjungiantis vienetus nuo kuopos iki strateginio lygmens štabo. Taigi, visi skirtinguose mokymuose dalyvaujantys vienetai vél tapo vieningo $V 2 R$ vartotojais.

Ši etapą, kaip ir turi būti, rugpjūčio 8-11 d. vèl pradejo GRP (oro desantas ir jūrų pèstininkai) dvišaliais mokymais Pskovo ir Kaliningrado regionuose. Pskove - parodomieji dvišaliai ODK pulko mokymai, kuriuose demonstruota pulko veiksmai puolant. Pirmoji bataliono taktinè grupe (BTG) desantuojasi su kovos technika ir užgrobia placdarmą (oro ouostą), antroji bataliono taktinè grupe stiprina pajègas, išsilaipindama užgrobtame oro uoste iš sraigtasparnių, o trečioji grupe BTG savo eiga forsuoja upę ir stiprina besiginančias pajègas $^{84}$. Puolančiuosius palaiko sava ODK artilerija, o iš oro remia naikintuvai-bombonešiai ir sraigtasparniai. Juose dalyvavo 76-osios ir 106-osios ODK divizijų, 31-osios, 45-osios brigadų ir 38-osios ODK ryšių brigados padaliniai. Bendras dalyvaujančiųjų skaičius viršija 2,5 tūkst. karių, apie 600 kovos technikos vienetų ir kelios dešimtys orlaivių 85868788899091 . Tuo pat metu, rugpjūčio 9 d., Kaliningrade, Chmeliovkos poligone, vyksta dvišaliai 336-osios jūrų

\footnotetext{
79 „В Западном военном округе проходят учения с соединениями связи“, Пресс-служба Западного военного округа, 2017-07-31.

80 „Более 500 связистов Балтийского флота вышли на учение“, Пресс-служба Западного военного округа, 2017-08-15, www.mil.ru.

81 „Связисты Балтфлота испытают на учениях современные средства связи“, Калининград, РИА Новости, 2017-08-15.

${ }^{82}$ ВДВ России в ходе пятидневных учений в СЗФО отработают весь спектр задач войск на период военного времени“, Интерфакс-АВН, 2017-08-07.

83 „В Западном военном округе проходят учения с соединениями связи“, Пресс-служба Западного военного округа, 2017-07-31.

84 „ВДВ России в ходе пятидневных учений в СЗФО отработают весь спектр задач войск на период военного времени“, Интерфакс-АВН, 2017-08-07.

85 „Батальон ВДВ при поддержке авиации отбил у „боевиков“ аэродром под Псковом“, Москва, TACC, 2017-08-09, http://tass.ru/armiya-i-opk/4471921

86 „ВДВ России в ходе пятидневных учений в СЗФО отработают весь спектр задач войск на период военного времени“, Интерфакс-АВН, 2017-08-07.

${ }^{87}$ „Новое оборудование для прыжков с большой высоты испытали в ходе учений ВДВ под

Псковом“, Псков, ТАСС, 2017-08-09, http://tass.ru/armiya-i-opk/4472182.

${ }^{88}$ „Десантники в ходе учений под Псковом ликвидировали лагерь условного НВФ“, Струги Красные (Псковская область), Интерфакс-АВН, 2017-08-10, www.militarynews.ru.

${ }^{89}$ „В полковых учениях ВДВ в Псковской области задействовано около 40 самолетов и вертолетов Минобороны РФ“, Псков, Интерфакс-АВН, 2017-08-08.

90 „Новое оборудование для прыжков с большой высоты испытали в ходе учений ВДВ под Псковом“ ПСКОВ, ТАСС, 2017-08-09, http://tass.ru/armiya-i-opk/4472182.

91 „В ноябре 104-й десантно-штурмовой полк ВДВ полностью перевооружат на БМД-4М и БТР-МДМ“, Аэродром Кислово (Псковская область), ТАСС, 2017-08-09, http://tass.ru/armiya-iopk/4472647.
} 
pėstininkų brigados ir 7-ojo atskiro motošaulių pulko mokymai. Čia apie 500 jūrų pėstininkų, remiami orlaivių ${ }^{92}$, puola placdarmą, kurị gina motošauliai ${ }^{93}$. Iš viso mokymuose dalyvavo daugiau kaip 2 tūkst. karių, 100 vienetų kovos technikos, 20 laivų ir 12 orlaivių. Jų veiksmus rèmé Baltijos laivynas ${ }^{94}$ ir aviacija $^{95}{ }^{96}$, kuri oficialiai vykde paramos iš oro mokymus, buvo pasitelkti karinių inžinierių ${ }^{97}$ ir elektroninès kovos vienetai ${ }^{98}$.

Kova už užimtus placdarmus tęsiasi. Sausumos pajègos stiprina oro ir krantų gynybą. Tą pačią rugpjūčio 9 dieną Kaliningrade esanti krantų gynybos brigada šaudo "Bal“ ir "Bastion“ sistemomis" ${ }^{99}$, o oro gynybos sistemos S-300 atremia masini priešo oro antskrydị ${ }^{100}$. Šalia vyksta dar vieni 11-ojo korpuso 79-osios atskiros motošaulių brigados ir 336-osios jūrų pestininkų brigados mokymai (apie 700 karių, 40 vnt. kovos technikos), kuriuose pėstininkai atremia priešo puolimus ${ }^{101}$. Rugpjūčio $11 \mathrm{~d}$. ì pagalbą 11-ojo korpuso ${ }^{102}{ }^{103}$ motošauliams ateina 79-osios atskiros motošaulių brigados elektroninès kovos pajègos

\footnotetext{
92 Масштабное учение морской пехоты Балтийского флота прошло в Калининградской области, Пресс-служба Западного военного округа, 2017-08-10, www.mil.ru.

93 „Морские пехотинцы Балтийского флота на учении в Калининградской области отрабатывают вопросы обороны побережья“, Пресс-служба Западного военного округа, 2017-08-16, www.mil.ru. 94 „Около 20 боевых кораблей и судов обеспечения Балтийского флота принимают участие в командно-штабной тренировке“, Пресс-служба Западного военного округа, 2017-08-15, www.mil.ru. 95 „Летчики Балтийского флота проводят практические ракетные стрельбы под Калининградом“, Калининград, ТАСС, 2017-08-14, http://tass.ru/armiya-i-opk/4481305.

96 „Морская авиация БФ поддержала высадку морского десанта на учении в Калининградской области“, Пресс-служба Западного военного округа, 2017-08-17, www.mil.ru.

97 „Инженеры Балтийского флота провели тактико-специальное учение“, пресс-служба 3ВО по Балтийскому флоту, 2017-08-10, https://yaostrov.ru/corps/ucheniya/item/52302-инженерыбалтийского-флота-провели-тактико-специальное-учение\#ixzz4qSNyoQqt.

98 „Подразделение РЭБ Балтийского флота подавило систему связи условного противника в ходе учения“, Пресс-служба Западного военного округа, 2017-08-11, www.mil.ru.

${ }^{99}$ С. Песоцкая, „Бал“ и „Бастион“ уничтожили корабли „противника“ на Балтике“, Российская газета, 2017-08-09, https://rg.ru/2017/08/09/reg-szfo/raketchiki-baltflota-unichtozhili-korabli-uslovnogoprotivnika.html.

100 „Комплексы С-300 сбили „нарушителей“ границы над Калининградом“, Российская газета, 2017-08-11, https://rg.ru/2017/08/11/reg-szfo/kompleksy-s-300-sbili-narushitelej-granicy-nad-kaliningradom.html.

${ }^{101}$ Мотострелки Балтийского флота уничтожат морской десант условного противника в ходе учения, Пресс-служба Западного военного округа, 2017-08-14, www.mil.ru.

102 „В Калининградской области проходит тактическое учение мотострелкового соединения армейского корпуса“, пресс-службы 3ВО по Балтийскому флоту, 2017-08-08, https://yaostrov. ru/corps/ucheniya/item/52296-в-калининградской-области-проходит-тактическое-учениемотострелкового-соединения-армейского-корпуса\#ixzz4qSP6QSbu.

103 „Полковое учение армейского корпуса началось в Калининградской области“, пресс-служба 3ВО по Балтийскому флоту, 2017-08-14, https://yaostrov.ru/corps/ucheniya/item/52306-полковое-учениеармейского-корпуса-началось-в-калининградской-области\#іхzz4qSNLnRzE.
} 
(apie 100 karių, 20 kovos technikos vnt.) ${ }^{104}$, kurios blokuoja priešo ryšius ${ }^{105}$ ir dengia savo pajėgas nuo oro antskrydžių. Mokymai, kuriuose vykdoma užimtų teritorijų gynyba ir įsitvirtinimas jose, tęsiasi. Visur intensyviai naudojama aviacija $^{106}$, artilerija ${ }^{107}$, elektroninè kova. I panašius veiksmus įsijungia JSV „Vakarai“ 20-oji operacinė vadovybė (OV), pradedanti dvišalius naujai sukurtų 3-iosios ir 144-osios divizijų mokymus. Jos padaliniai daro tai, ką darytų tokios operacijos metu, t. y. puola, persidislokuoja, pasipildo atsargas po mūšio ${ }^{108}{ }^{109}{ }^{110}$. Tą patị puolimą, gynybą, persidislokavimus poligonuose Maskvos, Nižnij-Novgorodo, Smolensko srityse ${ }^{111}$ po planinių mokymų pavadinimu pradeda 1-oji tankų OV (1-oji tankų armija). Vèl visur intensyviai naudojama artilerija ${ }^{112}$, aviacija, elektroninė kova113 114115 . Leningrado srityje JSV „Vakarai“ 6-osios OV 138-oji motošaulių brigada irgi atkartoja abiejų armijų divizijų veiksmus ${ }^{116} 117118$. Antrojo etapo pabaigoje ì veiksmus ịsijungia JSV „Branduolinės pajè-

\footnotetext{
104 „Под Калининградом начались учения мотострелков Балтфлота“, пресс-службы Балтийского флота, 2017-08-08, https://rg.ru/2017/08/08/reg-szfo/pod-kaliningradom-nachalis-takticheskoe-ucheniemotostrelkov-baltflota.html.

105 „Подразделение РЭБ Балтийского флота подавило систему связи условного противника в ходе учения“, Пресс-служба Западного военного округа, 2017-08-11, www.mil.ru.

106 „Авиаудары и высадка десанта на учениях морской пехоты Балтийского флота“, 2017-08-19, https://ria.ru/video/20170819/1500688024.html.

107 „Артиллеристы БФ провели учебно-боевые стрельбы с использованием беспилотников“, пресс-служба ЗВО по Балтийскому флоту, 2017-08-04, https://yaostrov.ru/corps/ucheniya/ item/52293-артиллеристы-бф-провели-учебно-боевые-стрельбы-с-использованиембеспилотников\#іхzz4qSPdgZbp.

108 „Более 2000 человек и 600 единиц техники поднято по тревоге в рамках двустороннего учения в Воронежской области“, Пресс-служба Западного военного округа, 2017-08-17, www.mil.ru. 109 „На учениях под Воронежем артиллеристы уничтожили базы „противника“, РИА Новости, 2017-08-20.

110 „Подразделение МТО на учении в Воронежской области обеспечит дозаправку топливом боевых машин в полевых условиях“, Пресс-служба Западного военного округа, 2017-08-15, www.mil.ru. 111 „В ЗВО по учебной тревоге подняли части Первой танковой армии“, С.-Петербург, РИА Новости, 2017-08-15, https://ria.ru/defense_safety/20170815/1500382408.html.

112 „Артиллеристы Таманской мотострелковой дивизии ЗВО отработают ведение высокоточной стрельбы“, Пресс-служба Западного военного округа, 2017-08-29, www.mil.ru.

113 „Артиллеристы 3ВО впервые применят новейшую модификацию «Мсты-С» на стрельбах под Нижним Новгородом“, Пресс-служба Западного военного округа, 2017-08-19, www.mil.ru. 114 „Расчеты РЭБ Западного военного округа подавили систему связи условного противника в Тамбовской области“, Пресс-служба Западного военного округа, 2017-08-28, www.mil.ru.

115 „Соединение РЭБ ЗВО поднято по тревоге на учение и совершает марш на незнакомый полигон в Тамбовской области“, 2017-08-17, http://function.mil.ru/news_page/country/more. htm?id=12138061@egNews.

116 „Более 1000 военнослужащих 3ВО участвует в двухстороннем БТУ под Санкт-Петербургом“, Пресс-служба Западного военного округа, 2017-08-17, www.mil.ru.

117 „Ударный батальон мотострелкового соединения 3ВО зажал «противника» в «огневом мешке“, Пресс-служба Западного военного округа, 2017-09-03, www.mil.ru.

118 „Тюльпаны» и «Пионы» уничтожили заглубленные командные пункты условного противника в Ленинградской области“, Пресс-служба Западного военного округа, 2017-08-29, www.mil.ru.
} 
gos" komponentai. Kaip skelbiama, planinius mokymus pradeda strateginès paskirties raketų pajègos. Net vienuolika strateginės paskirties raketų pulkų pasklinda po visą Rusiją, pradėdami mokymus, apimančius kovini patruliavimą ir kovą su priešo specialios paskirties pajègomis, siekiančiomis juos sunaikinti $^{119}$. Imituojami ir raketų paleidimai ${ }^{120}$. Kiti branduolinès triados elementai irgi įsitraukia: povandeninis laivas „Severodvinsk“ šaudo „Kalibr“ raketomis $^{121}$, o naikintuvų lydimi strateginès aviacijos bombonešiai atlieka strategini patruliavimą Ramiajame vandenyne ${ }^{122}$.

Apibendrinant šio etapo mokymus, matyti, kad visur vykdomas puolimas, skirtas išplessti sèkmę ir apginti jau kontroliuojamas teritorijas, ir pereinama prie strateginio atgrasymo tam, kad priverstų oponentą derètis. Veiksmai stipriai remiami iš oro didelio nuotolio tikslaus nutaikymo ginklais ir apsaugomi oro gynybos ir kitomis priemonèmis. Minètuose mokymuose (žr. 2 lentelę) galẻjo dalyvauti daugiau nei 27 tūkst. karių, apie 4200 kovos ir kitos karinès technikos ir ịrangos vienetų, apie 50 orlaivių ir apie 20 laivų. Ir vèl skirtingose Rusijos vietose vyko eilè mokymų, kurie irgi galètų būti laikomi šio etapo treniruotès dalimi, tačiau turimos medžiagos nepakanka tai patvirtinti.

2 lentelè. Zapad-17, tikètina, 2-asis etapas „Sẻkmès išplètimas ir sustiprinimas“

\begin{tabular}{|l|l|l|l|l|l|}
\hline $\begin{array}{l}\text { Data } \\
2017\end{array}$ & $\begin{array}{l}\text { Jungtiné } \\
\text { strateginè } \\
\text { vadovybé } \\
\text { JSV }\end{array}$ & Vienetai/Vieta & Dydis* & Veikla & Pastabos \\
\hline $\begin{array}{l}\text { Liepos } \\
\begin{array}{l}\text { Rugpjūčio } \\
?\end{array}\end{array}$ & JSV „Vakarai“ & $\begin{array}{l}3 \text { ryšių brig. } \\
\text { Nizhnij } \\
\text { Novgorodo, } \\
\text { Leningrado, } \\
\text { Voronežo, } \\
\text { Kaliningrado } \\
\text { sritys }\end{array}$ & $\begin{array}{l}+-5000 \mathrm{~K} \\
1000 \mathrm{KT}\end{array}$ & $\begin{array}{l}\text { Sukuria ir išlaiko } \\
\text { V2R tinklą }\end{array}$ & $\begin{array}{l}\text { Oficialiai - ne Zapad, } \\
\text { veiksmų sinchroni- } \\
\text { zacija ir pobūdis }\end{array}$ \\
\hline $\begin{array}{l}\text { Rugpjūčio } \\
\text { d. }\end{array}$ & JSV „Vakarai“ & $\begin{array}{l}11 \text {-asis korp. } \\
7-\text {-asis MP } \\
\text { Kaliningrado } \\
\text { sritis }\end{array}$ & $\begin{array}{l}+-500 \mathrm{~K} \\
65 \mathrm{KT}\end{array}$ & $\begin{array}{l}\text { Gynyba. Gina } \\
\text { pakrantę nuo } \\
\text { priešo pajègu } \\
\text { išsilaipinimo } \\
\text { (elektroninè kova, } \\
\text { artilerijos parama) }\end{array}$ & $\begin{array}{l}\text { Oficialiai - ne Zapad, } \\
\text { veiksmų sinchroni- } \\
\text { zacija ir pobūdis }\end{array}$ \\
\hline
\end{tabular}

\footnotetext{
119 „ПГРК «Тополь», «Тополь-М» и «Ярс» отрабатывают манёвренные действия на маршрутах боевого патрулирования в четырёх регионах России“, Департамент информации и массовых коммуникаций Министерства обороны Российской Федерации, 2017-08-15, www.mil.ru. 120 „Ракетчики проведут условные пуски из „Тополя“в Тверской области“, Москва,

TACC, 2017-08-17, http://tass.ru/armiya-i-opk/4488075.

121 „Подлодка в Баренцевом море провела стрельбу крылатой ракетой «Калибр»“, пресс-служба, Северного флота, 2017-08-18, https://iz.ru/634257/2017-08-18/podlodka-v-barentcevom-more-provelastrelbu-krylatoi-raketoi-kalibr.

122 „Ракетоносцы ВКС выполнили полеты над нейтральными водами в Тихом океане“, Москва, РИА Новости, 2017-08-24.
} 


\begin{tabular}{|c|c|c|c|c|c|}
\hline $\begin{array}{l}\text { Rugpjūčio } \\
8-11 \mathrm{~d} \text {. }\end{array}$ & $\begin{array}{l}\text { JSV Greitojo } \\
\text { reagavimo } \\
\text { pajėgos }\end{array}$ & $\begin{array}{l}\text { Transporto } \\
\text { Aviacijos OV }\end{array}$ & $\begin{array}{l}? \mathrm{~K} \\
40 \mathrm{O}\end{array}$ & $\begin{array}{l}\text { Puolimas. Greitojo } \\
\text { reagavimo pajègų } \\
\text { pergabenimas }\end{array}$ & $\begin{array}{l}\text { Oficialiai - ne Zapad, } \\
\text { veiksmu sinchroni- } \\
\text { zacija ir pobūdis }\end{array}$ \\
\hline $\begin{array}{l}\text { Rugpjūčio } \\
8-11 \mathrm{~d} \text {. }\end{array}$ & $\begin{array}{l}\text { JSV Greitojo } \\
\text { reagavimo } \\
\text { pajègos, } \\
\text { „Vakarai“ }\end{array}$ & $\begin{array}{l}76-o j i, 106-o j i \\
\text { DD, 31-oji, 45- } \\
\text { oji brig., 38-oji } \\
\text { ryšių brig. } \\
\text { Pskovas }\end{array}$ & $\begin{array}{l}+2500 \mathrm{~K} \\
+600 \mathrm{KT}\end{array}$ & $\begin{array}{l}\text { Puolimas. Pulko } \\
\text { mokymai puolant, } \\
\text { oro šturmas, oro } \\
\text { uosto užėmimas, } \\
\text { pastiprinimai ore } \\
\text { ir žemèje, reidai } \\
\text { priešo užnugaryje, } \\
\text { V2R sukūrimas }\end{array}$ & $\begin{array}{l}\text { Oficialiai - ne Zapad } \\
\text { veiksmų sinchroni- } \\
\text { zacija ir pobūdis }\end{array}$ \\
\hline $\begin{array}{l}\text { Rugpjūčio } \\
8 \mathrm{~d} \text {. }\end{array}$ & JSV „Vakarai“ & $\begin{array}{l}\text { 11-asis korp. } \\
79-o j i \text { MBbr. } \\
\text { Kaliningrado } \\
\text { sritis }\end{array}$ & $\begin{array}{l}+700 \mathrm{~K} \\
40 \mathrm{KT} \\
+4^{*} \mathrm{O}\end{array}$ & $\begin{array}{l}\text { Puolimas. } \\
\text { Bataliono taktinès } \\
\text { grupès mokymai } \\
\text { su artilerija ir } \\
\text { parama iš oro }\end{array}$ & $\begin{array}{l}\text { Oficialiai - ne Zapad, } \\
\text { veiksmų sinchroni- } \\
\text { zacija ir pobūdis }\end{array}$ \\
\hline $\begin{array}{l}\text { Rugpjūčio } \\
9 \text { d. }\end{array}$ & JSV „Vakarai“ & $\begin{array}{l}\text { 11-asis korp. } \\
25-0 j i \text { KGbr. } \\
\text { Kaliningrado } \\
\text { sritis }\end{array}$ & $\begin{array}{l}+-200 * \mathrm{~K} \\
+-10^{*} \mathrm{KT}\end{array}$ & $\begin{array}{l}\text { Puolimas, gynyba. } \\
\text { Neleisti oponento } \\
\text { laivams priplaukti }\end{array}$ & $\begin{array}{l}\text { Oficialiai - ne Zapad, } \\
\text { veiksmų sinchroni- } \\
\text { zacija ir pobūdis }\end{array}$ \\
\hline $\begin{array}{l}\text { Rugpjūčio } \\
9 \mathrm{~d} \text {. }\end{array}$ & $\begin{array}{l}\text { JSV Greitojo } \\
\text { reagavimo } \\
\text { pajėgos }\end{array}$ & $\begin{array}{l}336-o j i ~ J B r \\
\text { Kaliningrado } \\
\text { sritis }\end{array}$ & $\begin{array}{l}+-500 \mathrm{~K} \\
40 \mathrm{KT}\end{array}$ & $\begin{array}{l}\text { Puolimas. Jūrų } \\
\text { desantas, ugnies } \\
\text { parama iš laivų }\end{array}$ & $\begin{array}{l}\text { Oficialiai - ne Zapad, } \\
\text { veiksmų sinchroni- } \\
\text { zacija ir pobūdis }\end{array}$ \\
\hline $\begin{array}{l}\text { Rugpjūčio } \\
10 \text { d. }\end{array}$ & JSV „Vakarai“ & $\begin{array}{l}\text { Baltijos laivy- } \\
\text { nas, } \\
\text { Jūrų inžinieriai } \\
\text { Kaliningrado } \\
\text { sritis }\end{array}$ & $\begin{array}{l}+-150 \mathrm{~K} \\
20 \mathrm{KT}\end{array}$ & $\begin{array}{l}\text { Puolimas. Minų } \\
\text { užtvarų šalinimas } \\
\text { potencialaus jūrų } \\
\text { desanto vietoje }\end{array}$ & $\begin{array}{l}\text { Oficialiai - ne Zapad, } \\
\text { veiksmu sinchroni- } \\
\text { zacija ir pobūdis }\end{array}$ \\
\hline $\begin{array}{l}\text { Rugpjūčio } \\
10-16 \mathrm{~d} .\end{array}$ & JSV „Vakarai“ & $\begin{array}{l}\text { 11-asis korp. } \\
\text { 7-asis MP+ } \\
\text { 336-oji JBr. } \\
\text { Kaliningrado } \\
\text { sritis }\end{array}$ & $\begin{array}{l}+-2000 \mathrm{~K} \\
100 \mathrm{KT} \\
12 \mathrm{O}, 20 \mathrm{LA}\end{array}$ & $\begin{array}{l}\text { Puolimas, } \\
\text { gynyba. Dvišaliai } \\
\text { mokymai, jūru } \\
\text { pėstininkai puola, } \\
\text { motošauliai ginasi, } \\
\text { artilerija ir parama } \\
\text { iš oro }\end{array}$ & $\begin{array}{l}\text { Oficialiai - ne Zapad, } \\
\text { veiksmu sinchroni- } \\
\text { zacija ir pobūdis }\end{array}$ \\
\hline $\begin{array}{l}\text { Rugpjūčio } \\
11 \mathrm{~d} .\end{array}$ & JSV „Vakarai“ & $\begin{array}{l}\text { 11-asis korp. } \\
\text { Elektroninès } \\
\text { kovos vienetai } \\
\text { Kaliningrado } \\
\text { sritis }\end{array}$ & $\begin{array}{l}+-100 \mathrm{~K} \\
20 \mathrm{KT}\end{array}$ & $\begin{array}{l}\text { Puolimas, gy- } \\
\text { nyba. Potencialiai } \\
\text { remia dvišalius } \\
\text { jūrų pėstininkų } \\
\text { ir motošaulių } \\
\text { mokymus, } \\
\text { trikdžiai, SIGINT, } \\
\text { perdislokavimy } \\
\text { priedanga }\end{array}$ & $\begin{array}{l}\text { Oficialiai - ne Zapad, } \\
\text { veiksmų sinchroni- } \\
\text { zacija ir pobūdis }\end{array}$ \\
\hline $\begin{array}{l}\text { Rugpjūčio } \\
11 \text { d. }\end{array}$ & JSV „Vakarai“ & $\begin{array}{l}11 \text {-asis korp. } \\
\text { Oro gynybos } \\
\text { vienetai } \\
\text { Kaliningrado } \\
\text { sritis }\end{array}$ & $?$ & $\begin{array}{l}\text { Gynyba, puoli- } \\
\text { mas. Dvišaliai } \\
\text { Baltijos laivyno } \\
\text { aviacijos ir oro } \\
\text { gynybos (S300) } \\
\text { mokymai, teritori- } \\
\text { jos gynyba }\end{array}$ & $\begin{array}{l}\text { Oficialiai - ne Zapad, } \\
\text { veiksmu sinchroni- } \\
\text { zacija ir pobūdis }\end{array}$ \\
\hline $\begin{array}{l}\text { Rugpjūčio } \\
13 \mathrm{~d} .\end{array}$ & JSV „Vakarai“ & $\begin{array}{l}\text { 11-asis korp. } \\
X ? \text { motošaulių } \\
\text { vienetai } \\
\text { Kaliningrado } \\
\text { sritis }\end{array}$ & $?$ & $\begin{array}{l}\text { Puolimas. Tanku } \\
\text { igulų mokymai, } \\
\text { šaudyba ị ịvairius } \\
\text { taikinius, reaga- } \\
\text { vimas i naujas } \\
\text { jvadines }\end{array}$ & $\begin{array}{l}\text { Oficialiai - ne Zapad, } \\
\text { veiksmų sinchroni- } \\
\text { zacija ir pobūdis }\end{array}$ \\
\hline
\end{tabular}




\begin{tabular}{|c|c|c|c|c|c|}
\hline $\begin{array}{l}\text { Rugpjūčio } \\
14-18 \text { d. }\end{array}$ & JSV „Vakarai“ & $\begin{array}{l}\text { Baltijos laivyno } \\
\text { aviacija } \\
\text { Kaliningrado } \\
\text { sritis }\end{array}$ & $\begin{array}{l}+-500 \mathrm{~K} \\
20 \mathrm{KT}\end{array}$ & $\begin{array}{l}\text { Puolimas. Daly- } \\
\text { vauja dvišaliuose } \\
\text { mokymuose } \\
\text { su oro gynyba } \\
\text { (S300), pajègų } \\
\text { palaikymas iš } \\
\text { oro, oro erdvès } \\
\text { kontrolè }\end{array}$ & $\begin{array}{l}\text { Oficialiai - ne Zapad, } \\
\text { veiksmų sinchroni- } \\
\text { zacija ir pobūdis }\end{array}$ \\
\hline $\begin{array}{l}\text { Rugpjūčio } \\
14-18 \text { d. }\end{array}$ & JSV „Vakarai“ & $\begin{array}{l}\text { 20-oji OV } \\
\text { 3-iosios ir } \\
\text { 144-osios MD } \\
\text { Voronežo sritis }\end{array}$ & $\begin{array}{l}+-2000 \mathrm{~K} \\
600 \mathrm{KT}\end{array}$ & $\begin{array}{l}\text { Puolimas, gynyba. } \\
\text { Dvišaliai moky- } \\
\text { mai, aliarmas, } \\
\text { persidislokavimas, } \\
\text { veikla nežinomoje } \\
\text { vietovėje, logis- } \\
\text { tinis aprūpinimas }\end{array}$ & $\begin{array}{l}\text { Oficialiai - ne Zapad, } \\
\text { veiksmų sinchroni- } \\
\text { zacija ir pobūdis }\end{array}$ \\
\hline $\begin{array}{l}\text { Rugpjūčio } \\
15 \text { d. }\end{array}$ & JSV „Vakarai“ & $\begin{array}{l}\text { Baltijos laivy- } \\
\text { nas, } \\
\text { Ryšių vienetai } \\
\text { Kaliningrado } \\
\text { sritis }\end{array}$ & $500 \mathrm{~K}$ & $\begin{array}{l}\text { Ryšių pratybos, } \\
\text { V2R išlaikymas. } \\
\text { Tikriausiai JSV } \\
\text { ryšių pratybų dalis }\end{array}$ & $\begin{array}{l}\text { Oficialiai - ne Zapad, } \\
\text { veiksmų sinchroni- } \\
\text { zacija ir pobūdis }\end{array}$ \\
\hline $\begin{array}{l}\text { Rugpjūčio } \\
15 \text { d. }\end{array}$ & JSV „Vakarai“ & $\begin{array}{l}\text { Baltijos laivy- } \\
\text { nas } \\
\text { Baltijos jūra }\end{array}$ & $\begin{array}{l}+-1000 \mathrm{~K} \\
20 \mathrm{~L}\end{array}$ & $\begin{array}{l}\text { Gynyba, puoli- } \\
\text { mas. Vadovybès } \\
\text { treniruotè, skir- } \\
\text { tingi laivų veiksmai } \\
\text { jūroje }\end{array}$ & $\begin{array}{l}\text { Oficialiai - ne Zapad, } \\
\text { veiksmų sinchroni- } \\
\text { zacija ir pobūdis }\end{array}$ \\
\hline $\begin{array}{l}\text { Rugpjūčio } \\
15-? \text { d. }\end{array}$ & JSV „Vakarai“ & $\begin{array}{l}\text { 1-oji tankų OV } \\
\text { (60-oji ryšių } \\
\text { brig., 2-oji MD, } \\
\text { 4-oji TD, 228- } \\
\text { oji artilerijos } \\
\text { brig., 112-oji } \\
\text { raketų brig., } \\
\text { 53-oji oro } \\
\text { gynybos brig., } \\
\text { 20-asis ABC } \\
\text { pulkas } \\
\text { Maskvos, } \\
\text { Smolensko, } \\
\text { Ivanovo, Nižnij } \\
\text { Novgorodo } \\
\text { sritys }\end{array}$ & $\begin{array}{l}+-5000 \mathrm{~K}^{*} \\
1000 \mathrm{KT}\end{array}$ & $\begin{array}{l}\text { Puolimas, } \\
\text { gynyba. Aliarmas, } \\
\text { persidislokavimai, } \\
\text { puolimas, teritoriju } \\
\text { gynyba, V2R } \\
\text { sukūrimas }\end{array}$ & $\begin{array}{l}\text { Oficialiai - ne Zapad, } \\
\text { veiksmų sinchroni- } \\
\text { zacija ir pobūdis }\end{array}$ \\
\hline $\begin{array}{l}\text { Rugpjūčio } \\
15-? \text { d. }\end{array}$ & $\begin{array}{l}\text { JSV } \\
\text { Branduolinès } \\
\text { pajėgos }\end{array}$ & $\begin{array}{l}\text { Strateginių } \\
\text { raketų OV, } \\
\text { vienuolika } \\
\text { mobiliujų raketų } \\
\text { pulku } \\
4 \text { Rusijos } \\
\text { regionai }\end{array}$ & $\begin{array}{l}+-2000 \mathrm{~K} \\
400 \mathrm{KT}\end{array}$ & $\begin{array}{l}\text { Gynyba. } \\
\text { Strateginių } \\
\text { raketų išvedimas } \\
\text { ì patruliavimą, } \\
\text { raketu „Topol“ pa- } \\
\text { leidimo imitacija }\end{array}$ & $\begin{array}{l}\text { Oficialiai - ne Zapad, } \\
\text { veiksmy sinchroni- } \\
\text { zacija ir pobūdis }\end{array}$ \\
\hline $\begin{array}{l}\text { Rugpjūčio } \\
17 \text { d. }\end{array}$ & JSV „Vakarai“ & $\begin{array}{l}\text { 6-oji OV } \\
138-0 j i \\
\text { motošaulių } \\
\text { brig. } \\
\text { Leningrado } \\
\text { sritis }\end{array}$ & $\begin{array}{l}+-1000 \mathrm{~K} \\
100 \mathrm{KT}\end{array}$ & $\begin{array}{l}\text { Puolimas, gynyba. } \\
\text { Dvišaliai brigados } \\
\text { BTG mokymai, } \\
\text { V2R steigimas, } \\
\text { persidislokavimai, } \\
\text { šaudymai, UAV } \\
\text { panaudojimas, } \\
\text { sąveika su } \\
\text { artilerija }\end{array}$ & $\begin{array}{l}\text { Oficialiai - ne Zapad, } \\
\text { veiksmų sinchroni- } \\
\text { zacija ir pobūdis }\end{array}$ \\
\hline
\end{tabular}




\begin{tabular}{|c|c|c|c|c|c|}
\hline $\begin{array}{l}\text { Rugpjūčio } \\
17 \mathrm{~d} \text {. }\end{array}$ & JSV „Vakarai“ & $\begin{array}{l}16-\text { oji } \\
\text { elektroninès } \\
\text { kovos brig. } \\
\text { Tambovo sritis }\end{array}$ & $\begin{array}{l}+-500 \mathrm{~K} \\
100 \mathrm{KT}\end{array}$ & $\begin{array}{l}\text { Puolimas. } \\
\text { Priešininko ryšių } \\
\text { trikdymas, savo } \\
\text { pajėgu priedanga } \\
\text { nuo aviacijos }\end{array}$ & $\begin{array}{l}\text { Oficialiai - ne Zapad, } \\
\text { veiksmų sinchroni- } \\
\text { zacija ir pobūdis }\end{array}$ \\
\hline $\begin{array}{l}\text { Rugpjūčio } \\
17 \mathrm{~d} \text {. }\end{array}$ & JSV „Vakarai“ & $\begin{array}{l}\text { Aviacijos } \\
\text { vienetai } \\
\text { Kursko sritis }\end{array}$ & 100 & $\begin{array}{l}\text { Puolimas. Oras- } \\
\text { oras mūšiai, oro } \\
\text { erdvès kontrolè, } \\
\text { parama sausumos } \\
\text { pajėgoms }\end{array}$ & $\begin{array}{l}\text { Oficialiai - ne Zapad, } \\
\text { veiksmų sinchroni- } \\
\text { zacija ir pobūdis }\end{array}$ \\
\hline $\begin{array}{l}\text { Rugpjūčio } \\
17 \mathrm{~d} \text {. }\end{array}$ & JSV „Vakarai“ & $\begin{array}{l}20-o j i ~ O V \\
\text { Artilerijos, } \\
\text { Žvalgybos } \\
\text { vienetai/skirtin- } \\
\text { gos vietos }\end{array}$ & $?$ & $\begin{array}{l}\text { Puolimas. } \\
\text { Tikriausiai } 20 \text { OV } \\
\text { rugpjūčio 14-18 } \\
\text { d. dalis }\end{array}$ & $\begin{array}{l}\text { Oficialiai - ne Zapad, } \\
\text { veiksmų sinchroni- } \\
\text { zacija ir pobūdis }\end{array}$ \\
\hline Rugpjūčio & $\begin{array}{l}\text { JSV } \\
\text { Branduolinès } \\
\text { pajègos }\end{array}$ & $\begin{array}{l}\text { Šiaurès laivyno } \\
\text { povandeninès } \\
\text { pajejgos } \\
\text { PL „Severod- } \\
\text { vinsk“ } \\
\text { Barenco jūra }\end{array}$ & $1 \mathrm{PL}$ & $\begin{array}{l}\text { Sparnuotosios } \\
\text { raketos „Kaliber“ } \\
\text { paleidimas. Dis- } \\
\text { tancija - } 600 \mathrm{~km}\end{array}$ & $\begin{array}{l}\text { Oficialiai - ne Zapad, } \\
\text { veiksmų sinchroni- } \\
\text { zacija ir pobūdis }\end{array}$ \\
\hline $\begin{array}{l}\text { Rugpjūčio } \\
19 \mathrm{~d} \text {. }\end{array}$ & JSV „Vakarai“ & $\begin{array}{l}\text { 1-osios tanku } \\
\text { OV } \\
\text { artilerijos } \\
\text { vienetai } \\
\text { Nižnij Novgoro- } \\
\text { do sritis }\end{array}$ & $\begin{array}{l}+-1000 \mathrm{~K} \\
300 \mathrm{KT}\end{array}$ & $\begin{array}{l}\text { Puolimas. Tikriau- } \\
\text { siai, 1-osios OV } \\
\text { mokymų rugpjūčio } \\
\text { 15-? d. dalis }\end{array}$ & $\begin{array}{l}\text { Oficialiai - ne Zapad, } \\
\text { veiksmų sinchroni- } \\
\text { zacija ir pobūdis }\end{array}$ \\
\hline $\begin{array}{l}\text { Rugpjūčio } \\
23 \mathrm{~d} \text {. }\end{array}$ & $\begin{array}{l}\text { JSV } \\
\text { Branduolinès } \\
\text { pajėgos }\end{array}$ & $\begin{array}{l}\text { Strateginès } \\
\text { aviacijos OV }\end{array}$ & $2-60$ & $\begin{array}{l}\text { Puolimas, gynyba. } \\
\text { Strateginès aviaci- } \\
\text { jos patrulis virš } \\
\text { Japonijos, Gel- } \\
\text { tonosios ir pietų } \\
\text { Kinijos jūrų. A-50 } \\
\text { ir užpildymas ore }\end{array}$ & $\begin{array}{l}\text { Oficialiai - ne Zapad, } \\
\text { veiksmų sinchroni- } \\
\text { zacija ir pobūdis }\end{array}$ \\
\hline $\begin{array}{l}\text { Rugpjūčio } \\
23-25 \text { d. }\end{array}$ & JSV „Vakarai“ & $\begin{array}{l}\text { 6-oji oro OV } \\
\text { Kurskas- } \\
\text { Astrachanè }\end{array}$ & $\begin{array}{l}+-100 \mathrm{~K} \\
15 \mathrm{O}\end{array}$ & $\begin{array}{l}\text { Gynyba, puoli- } \\
\text { mas. Persidis- } \\
\text { lokavimas i atsar- } \\
\text { ginius aerodromus }\end{array}$ & $\begin{array}{l}\text { Oficialiai - ne Zapad, } \\
\text { veiksmų sinchroni- } \\
\text { zacija ir pobūdis }\end{array}$ \\
\hline IŠ VISO: & & & $\begin{array}{l}-+27000 \mathrm{~K} \\
+-4200 \mathrm{KT} \\
-+55 \mathrm{O} \\
20 \mathrm{~L}\end{array}$ & & \\
\hline
\end{tabular}

${ }^{*}$ Visi skaičiai yra iš atvirų šaltinių arba išskaičiuoti. I galima tu pačiu karių dalyvavima skirtinguose veiksmuose atsižvelgta.

Legenda. JSV - jungtinè strateginė vadovybè, OV - operacinè vadovybè, brig. - brigada, MP - motošaulių pulkas, MD - motošaulių divizija, TD - tankų divizija, DD - oro desanto divizija, JBr. - jūrų pėstininkų brigada, KGbr. - krantų gynybos brigada, $\mathrm{K}$ - kariai/jūreiviai, KT - karinè technika (kovos ir kt.), L - laivai: LA - antvandeniniai laivai, PL - povandeniniai laivai, KL - kiti laivai, O - orlaiviai, Lek. - lëktuvai, Sr. - sraigtasparniai. 


\subsubsection{Zapad-17. „Zapad operacijos“ trečiasis etapas}

Trečiojo „Zapad operacijos“ etapo - plataus masto visos valstybės gynybos, pasitelkiant visus pajegumus ir pralaimejjimo atveju pereinančios ị branduolinị karą - treniruotè prasidejjo rugsejo mèn. (11-23 d.). Kaip ir ankstesnių etapų metu, daug greito reagavimo, bendros paskirties branduolinių pajègu vienetų bei kitų valstybès jègos institucijų (Nacionalinès gvardijos, Ypatingų situacijų ministerijos ir t. t.) pajègų mokymai, dvišaliai, planiniai, atrodytų visiškai nesusieti vieni su kitais, buvo labai koordinuoti ir sinchroniški. Svarbiausia, visi veiksmai pilnai atitiko šio etapo esmę - visuotinę valstybès gynybą (su kontrpuolimo elementais). İ ši etapą pateko ir oficialiai paskelbtos Zapad-17 dienos, kurių metų organizuota parodomoji programa žurnalistams ir stebètojams iš užsienio. Ji buvo skirta pademonstruoti trečiojo etapo veiksmus - plataus masto gynyba su kontrpuolimo elementais.

Kaip ir ankstesnių etapų metu, vèl sukurtas vieningas V2R. Visos mokymuose dalyvavusios greitojo reagavimo ir bendrosios paskirties pajègos išskleide mobilų V2R tinklą, aktyvavo dirbusius realaus laiko režimu valdymo punktus ${ }^{123}$ ${ }^{124}$, naudojo automatizuotas mūšio valdymo sistemas (Andromeda-D., Poliot$\mathrm{K}^{125}$ ir t. t.). Taip buvo užtikrintas $1000 \mathrm{~km}^{126}-2000 \mathrm{~km} .{ }^{127}$ atstumu vienas nuo kito mokymus vykdančių pajègų veiksmų sinchorizavimas ir sukurta nuo kareivio iki aukščiausiojo štabo išplitusi informacinè-valdymo sistema ${ }^{128}$.

Šis etapas prasidejjo labai ịdomiai. Rugsèjo $12 \mathrm{~d}$. paleista šachtinio bazavimo tarpkontinentinè balistinè raketa "Jars"129. Tarpkontinentinés balistinès raketos, skirtingai nuo trumpo nuotolio, strateginių bombonešių ar povandeninių laivų, neša tik branduolinį užtaisą, taigi, nors ịvardintas kaip bandomasis, iš esmès, šis šūvis pradejo paskutiniji - visuotinès gynybos - etapą. Jame šalis pradeda naudoti strateginius branduolinius ginklus. Paleidimas „atsitiktinai“

\footnotetext{
123 „Связисты Балтийского флота проводят учения в полевых условиях“, Пресс-служба Западного военного округа, 2017-08-13, www.mil.ru.

124 „Сеть скрытых командных пунктов создана в рамках учений «Запад-2017»“, https://tvzvezda.ru/ news/forces/content/201709201215-4fls.htm.

125 „Подразделения ВДВ оборудовали скрытые полевые пункты управления в рамках ССУ

«Запад-2017»“, 2017-09-18, www.mil.ru.

126 „Военные связисты России и Белоруссии создали защищенную линию связи длиной около 1000 км для обеспечения учения «Запад-2017»", 2017-09-15, www.mil.ru.

127 „На учении «Запад-2017» связисты ВДВ обеспечивают пункты управления связью на расстоянии до 2 тыс. Км“, 2017-09-16, www.mil.ru.

128 „Учения „Запад-2017“: проверка „нервной системы“ российской армии“, Москва, ТАСС, 2017-09-19.

129 „Россия выполнила испытательный пуск межконтинентальной ракеты „Ярс“ с разделяющейся головной частью“, Москва, Интерфакс-АВН, 2017-09-20.
} 
sutapo su labai keistu ịvykiu, privertusiu vykdyti veiksmus, kurie tikrai vyktu tuo atveju, kai panaudojamas branduolinis ginklas. Tas keistas ịvykis buvo $\mathrm{Ru}-$ sijoje prasidèjusi anoniminių skambučių apie padètus sprogmenis lavina, kuri, iš esmès, tęsiasi ir iki šiol. Nors oficialūs pareigūnai suskubo teigti, kad tai nèra mokymai ${ }^{130}$, tai neturi jokio sąryšio su mokymais ${ }^{131}$ arba tai yra organizuota iš užsienio provokacija ${ }^{132}$, tačiau susidariusi situacija suteikè pretekstą naujai sukurtai Rusijos nacionalinei gvardijai, Ypatingų situacijų ministerijai, FSB ir kitoms struktūroms daryti tai, ką jos darytų tokiais atvejais, t. y. imtis masinès civilinių objektų, gyventojų evakuacijos. Per pirmąją skambučių bangą, trukusią tris dienas, nuo rugsèjo 10 iki $12 \mathrm{~d}$., ir apėmusią Rusijos teritoriją nuo Kaliningrado ${ }^{133}$ iki Omsko, buvo evakuota kelios dešimtys objektų, pradedant administraciniais pastatais ir baigiant prekybos centrais, o realiai evakuotųjų skaičius siekè 45 tūkstančius ${ }^{134}$. Kiek tūkstančių Nacionalinès gvardijos ir kitų jẻgos struktūrų karių evakavo žmones, saugojo ir tikrino objektus, pasakyti sunku, tačiau tai bus tikrai tūkstančiai. Žinant, kad visos tos tarnybos yra ịtrauktos ị NGVC V2R tinklą ir gali būti (ir, tikriausiai, buvo) iš jo valdomos, trečiasis etapas iš pat pradžių tapo labai realus.

Pabandykime atkurti trečiojo etapo scenarijų, remiantis veiksmais, kuriuos tuo metu vykdè pajègos. Bendrosios paskirties pajègos pradejo plataus masto gynybą. Gynybą, kuri, tikriausiai, vyktų tuo atveju, kai, nepavykus pasiekti pirmajam ir antrajam etapams keliamų tikslų, tektų susiremti su Vakarų (NATO) pajègomis, kurios okupuotoms teritorijoms išvaduoti imtųsi plataus masto konvencinių veiksmų.

Visur šio etapo pradžioje vyrauja gynyba. Ji pradedama beveik tuo pat metu visame, kaip Gynybos ministerija įvardijo, $600 \mathrm{~km}$ ilgio fronte ${ }^{135}$. Kaliningrado srityje 11-ojo korpuso pajègos pradeda, kaip skelbiama, planines pra-

\footnotetext{
130 „Глава МЧС опроверг версию „учений“ в связи с массовой эвакуацией людей в регионах РФ“, Москва, INTERFAX.RU, 2017-09-20.

131 „Глава МЧС: эвакуации в городах России из-за анонимных звонков не связаны с учениями“, ttps://www.kommersant.ru/doc/3416054.

132 „Генерал ФСБ отметил сезонность анонимных звонков с угрозами взрывов“, Москва, РИА Новости, 2017-09-12.

${ }^{133}$ „В Калининграде проверяют анонимные сообщения о минировании зданий“, Калининград, РИА Новости, 2017-09-12.

${ }^{134}$ https://meduza.io/feature/2017/09/12/evakuatsiya-tysyach-lyudey-iz-torgovyh-tsentrov-shkol-vuzovadministratsiy-i-gostinits-po-vsey-rossii-chto-proishodit.

135 „Путин и Шойгу оценили итоги учений „Запад-2017“ на Лужском полигоне“, Полигон Лужский, РИА Новости, 2017-09-18.
} 
tybas, skirtas gynybai ${ }^{136}{ }^{137}$. Prie ju prisijungia srityje dislokuotos aviacijos ir oro erdvès gynybos sistemų S300, S400 138139140 bei specialių pajègų vykdomos kovos su priešo koviniais plaukikais ${ }^{141}$ pratybos. Leningrado srityje, Pečengos poligone, apie 1500 motošaulių, remiamų 300 vnt. kovos technikos vienetų, issirengineja pozicijas ir ruošiasi gynybai ${ }^{142}$. Prie Murmansko esančiame $\mathrm{Pu}-$ manki poligone 600 jūrų pèstininkų ir apie 300 vnt. kovos technikos, artilerijos ir aviacijos remiami ruošiasi atremti jūrų desanto išsilaipinimą ${ }^{143}$. 1-osios tankų armijos 6-oji tankų brigada geležinkelio stotyse kraunasi i ešelonus, ruošdamasi sustiprinti bendras Rusijos-Baltarusijos pajėgas ${ }^{144}$, kurios, savo ruožtu, Baltarusijos poligonuose irgi rengiasi gynybai ${ }^{145}$. Šiaurès ${ }^{146}$ ir Baltijos ${ }^{147}$ laivynai išplaukia iš nuolatinių bazavimo vietų ị operacinius rajonus ${ }^{148}$ ir pradeda gynybos nuo priešo aviacijos ir laivyno ${ }^{149} 150151$ pratybas. Tą patį daro JSV

\footnotetext{
${ }^{136}$ „В Калининградской области проходит учение с подразделениями армейского корпуса Балтийского флота“, Отдел информационного обеспечения Балтийского региона (г. Калининград), 2017-09-13, www.mil.ru.

137 „Сухопутные подразделения Балтийского флота отрабатывают действия в обороне в рамках учения «Запад-2017»“, 2017-09-16, www.mil.ru.

138 „В ходе учения „Запад-2017“ военные проверили работу дежурных сил ПВО“, Москва, Интерфакс-АВН, 2017-09-14.

139 „Силы ПВО Балтфлота на учениях „Запад-2017“ уничтожили ракеты условного противника“, Калининград, ТАСС, 2017-09-15, http://tass.ru/armiya-i-opk/4563969.

140 „Подразделения противовоздушной обороны Балтийского флота отразили авиационный удар“, Отдел информационного обеспечения Балтийского региона (г. Калининград), 2017-09-15, www.mil.ru. 141 „На Балтийском флоте в рамках ССУ «Запад-2017» бойцы отряда ПДСС задержали условных подводных диверсантов“, 2017-09-15, www.mil.ru.

142 „В Заполярье завершилось тактическое учение с подразделениями армейского корпуса Северного флота“, Пресс-служба Северного флота, 2017-09-15, www.mil.ru.

143 „Морпехи Северного флота на учениях отразили высадку десанта на Кольский полуостров“, Мурманск, ТАСС, 2017-09-18, http://tass.ru/armiya-i-opk/4571107.

144 „Танковая бригада из Подмосковья перебрасывается в Белоруссию на учения“, Москва, Интерфакс-АВН, 2017-09-14.

145 „Подразделения 3ВО заняли оборонительные рубежи на белорусском военном полигоне Осиповичский в рамках ССУ «Запад-2017»“, 2017-09-16, www.mil.ru.

146 „В Баренцевом море начались учения Северного флота“, Пресс-служба Северного флота, РИА Новости, 2017-09-14.

147 „Корабли Балтийского флота вышли в море на учениях «Запад-2017“, Пресс-служба Западного военного округа, 2017-09-16, http://kgd.ru/news/society/item/66883-korabli-baltijskogo-flota-vyshli-vmore-na-ucheniyah-zapad-2017.

148 „Силы Беломорской военно-морской базы Северного флота развёрнуты в Баренцевом море“, Пресс-служба Северного флота, 2017-09-16, www.mil.ru.

149 „Корабельная ударная группа и истребительная авиация СФ отразили воздушные атаки условного противника в Баренцевом море“, Пресс-служба Северного флота, 2017-09-15, www.mil.ru.

150 „Корвет Балтфлота в ходе учения „Запад-2017“ поразил крылатой ракетой корабль условного противника“, Балтийск. пресс-службе Балтфлота РФ, Интерфакс, 2017-09-19.

151 „Корабли Балтфлота выполнили артиллерийские стрельбы на учениях „Запад-2017“, отдела информационного обеспечения пресс-службы $3 В О$ по Балтийскому флоту, 2017-09-17, Балтийск (Калининградская область), РИА Новости, 2017-09-17.
} 
„Vakarai“, 6-osios aviacijos OV pajegos, kurių orlaiviai skubiai perdislokuojami $\mathfrak{i}$ atsarginius aerodromus ${ }^{152}$. Gynybai pasitelkiamos specializuotosios pajègos. JSV „Vakarai“ cheminès, radiacinès ir biologinès apsaugos vienetų kariai Lugos poligone demonstruoja gebą maskuoti pajègų persidislokavimą aerozoliniais dūmais ${ }^{153}$, o elektroninio karo specialistai - apsaugoti pajègas nuo priešo žvalgybos iš oro ${ }^{154}$ bei kibernetinių atakų, skirtų suardyti gynybai sukurtą V2R sistemą ${ }^{155}$.

Puolantị priešą stabdyti dar iki tiesioginio kontakto su juo naudojamos aviacinès (sraigtasparnių) pasalos ${ }^{156}$ ir didelio nuotolio tikslaus nutaikymo ginklas. Tai daro raketų brigados, kurios „Iskander“ ir „Točka-U“ raketomis smogia i priešo valdymo punktus ir pajègų sutelkimo rajonus ${ }^{157}{ }^{158}$. Tą patị tik realios kovinès operacijos rèmuose Viduržemio jūroje atlieka povandeniniai laivai „Didysis Novgorodas“ ir „Kalino“, raketomis „Kalibr“ apšaudydami taikinius Sirijo$\mathrm{je}^{159}$. I stabdymo operacijas ittraukiamos greitojo reagavimo pajègos. Oro desanto kariai ${ }^{160}$ vykdo kovinius reidus arba desantuojami į priešo užnugarị, kur vykdo diversijas, parenka taikinius ir kitaip trikdo priešą ${ }^{161}$. Gynybiniuose mūšiuose patiriamiems nuostoliams atstatyti logistikos pajegos atlieka pažeistos kovos technikos evakuacijos ir atstatymo ${ }^{162}$ ir savo vienetų aprūpinimo pratybas ${ }^{163}$.

Vis labiau įsitraukiant ị gynybinius mūšius, kuriuose priešas sustabdo-

\footnotetext{
152 „Авиация 3ВО передислоцируется на оперативные аэродромы в рамках проведения ССУ «Запад-2017»“, 2017-09-15, www.mil.ru.

153 „Специалисты РХБ защиты ЗВО скрыли передислокацию войск на учении «Запад-2017», 2017-09-15, www.mil.ru.

154 „Военные специалисты РЭБ ЗВО на учении «Запад-2017» прикрыли развертывание войск союзников от беспилотников «противника»“, 2017-09-15, www.mil.ru.

155 „Военные связисты ЗВО отразили кибератаки «противника» на учении «Запад-2017»“,

2017-09-15, www.mil.ru.

156 „Вертолеты ЗВО продемонстрировали тактику уничтожения высокомобильного «противника» из засад в ходе учения «Запад-2017»", 2017-09-17, www.mil.ru.

157 „Ракетчики 3ВО в ходе ССУ «Запад-2017» уничтожили военную технику и командный пункт условного противника на полигоне в Ленинградской области“, 2017-09-17, www.mil.ru.

${ }^{158}$ TV žinios RTR „Vesti“,19.00, 2017-09-16.

159 „Подлодки “Великий Новгород” и „Колпино“ нанесли удар „Калибрами“ по объектам ИГ в Сирии“, Москва, ТАСС, 2017-09-14, http://tass.ru/armiya-i-opk/4561914.

160 „В ходе учения „Запад-2017“ поднят по тревоге ряд подразделений ВДВ России“, Москва, Интерфакс-АВН, 2017-09-14.

161 „«Ульяновское соединение ВДВ проведет первое тактическое учение с применением боевых машин БМД-4М и БТР-МДМ «Ракушка»", Департамент информации и массовых коммуникаций Министерства обороны Российской Федерации, 2017-09-13, www.mil.ru.

162 „Специалисты МТО проведут в ходе ССУ «Запад-2017» тренировки по обслуживанию и экстренному ремонту ВВТ“, 2017-09-16, www.mil.ru.

163 „Бригада материально-технического обеспечения 3ВО в ходе учения «Запад-2017» развернула ремонтные мастерские“, 2017-09-16, www.mil.ru.
} 
mas $^{164} 165$, pradedama rengtis kontrsmūgiams ${ }^{166}$ : visame fronte nuo Leningrado $^{167}$ iki Kaliningrado ${ }^{168}$ ir Baltarusijos pereinama ị kontrpuolimą. Ypatingas dèmesys vèl skiriamas, organizuojant puolančiųjų paramą iš oro ${ }^{169}{ }^{170}$. Antroje oficialių Zapad-17 mokymų puseje praktiškai visuose frontuose vykdomi tokie sèkmingi kontrsmūgiai ${ }^{171}$, kad pralaimintys Vakarai priversti panaudoti kraštutines priemones, t. y. branduolini ginklą, todèl Rusijoje tuo metu plūsteli antroji anoniminių skambučių apie minavimą banga. Jie ir toliau skelbiami nesusietais su mokymais, tačiau, reaguodama $\mathfrak{i}$ juos, Nacionaline gvardija ir kitos pajègos vienuolikoje miestų (daugiausiai vakarinèje ir pietinèje Rusijos dalyse) tęsia masines objektų patikras ir gyventojų evakuacijas. Ši kartą realiai evakuojama daugiau nei 200 tūkst. žmonių, patikrinama virš 700 objektų ${ }^{172}$. Panašu, kad taip Rusijos kariškai modeliuoja situaciją, kai Vakarai, stabdydami jos puolimą, smūgiuoja ị Rusijos gilumą.

Gynybos ministerija $\mathfrak{i}$ tai atsako branduoliniais smūgiais. Juos imituoja Kopustino Jaro poligone atliktas „Iskanderio“ raketos, galinčios nešti branduolinį užtaisą, paleidimas maksimaliu nuotoliu ${ }^{173}$, tarpkontinentinès balistinés raketos „Jars“ nuo mobiliosios platformos paleidimas Plesecko kosmodrome ${ }^{174}$ ir strateginių bombonešių Tu 22M3 paleidimas vèl skelbiamas kaip planinis skrydis virš Baltijos Jūros ir palei Norvegiją ${ }^{175}$. Po keletos dienų Gynybos mi-

\footnotetext{
${ }^{164}$ „Мотострелки общевойсковой армии ЗВО уничтожили десант НВФ в ходе основного этапа учения «Запад-2017»“, 2017-09-17, www.mil.ru.

165 „Лётчики Балтфлота уничтожили подлодку условного противника на учениях «Запад-2017“,

Минобороны РФ, 2017-09-16, http://kgd.ru/news/society/item/66895-ljotchiki-baltflota-unichtozhilipodlodku-uslovnogo-protivnika-na-ucheniyah-zapad-2017.

166 „Подразделения ВДВ готовятся к погрузке в самолеты ВТА для последующего применения в качестве парашютного тактического десанта“, 2017-09-17, www.mil.ru.

167 „Су-25 на учениях „Запад-2017“ уничтожили колонну „противника“, департамент информации и массовых коммуникаций Минобороны России, С.-Петербург, РИА Новости, 2017-09-18.

168 „Су-24 выполнили практическое бомбометание на учениях „Запад-2017“, пресс-служба

Западного военного округа (ЗВО) по Балтийскому флоту, Калининград, РИА Новости, 2017-09-17. 169 „Российские Су-24М на учениях „Запад-2017“ уничтожили объекты „противника“, С.-Петербург, РИА Новости, 2017-09-18.

170 Экипажи ударных вертолетов 3ВО выполнили прикрытие наземной группировки войск с воздуха в рамках учения «Запад-2017», 2017-09-17, www.mil.ru.

171 „Мотострелки Балтийского флота под Калининградом ликвидировали условных террористов в ходе маневров „Запад-2017“, Полигон „Правдинский“ (Калининградская область), ИнтерфаксАВН, 2017-09-18.

${ }_{172}$ А. Гальперин, „Более 200 тысяч человек эвакуировали в РФ за неделю из-за звонков анонимов“, Москва, РИА Новости, 2017-09-19.

173 „Комплекс „Искандер-М“ на учениях запустил ракету на максимальную дальность“, Москва, РИА Новости, 2017-09-18.

174 „Испытательный пуск: ракета «Ярс» поразила цель на Камчатке“, 2017-09-20, https://tvzvezda.ru/ news/forces/content/201709201139-d0to.htm.

175 „Бомбардировщики Ту-22М3 совершили плановые полеты над нейтральными водами Балтийского и Норвежского морей“, 2017-09-21, https://tvzvezda.ru/news/forces/ content/201709210004-urtl.htm.
} 
nisterija pradeda visų JSV pajėgų kompleksini patikrinimą. Jau ne dešimtys, o šimtai dalinių ir junginių visoje Rusijoje tikrinami, išvedami iš nuolatinès dislokacijos vietų, o poligonuose vykdomos įvairios užduotys. Rusijoje anoniminiai skambučiai tęsiasi, todèl Nacionalinė gvardija ir kitos struktūros, kaip ir NGVC, ir toliau intensyviai dirba. Bendrai nuo skambučiu pradžios iki spalio antrosios pusės Nacionalinè gvardija ir kitos struktūros 170 miestų patikrino apie 2,46 tūkst. objektų ${ }^{176}$ ir realiai evakavo apie 1 proc. visų Rusijos gyventojų, t. y. 1.4 milijono žmonių ${ }^{177}$. Tokia situacija, tikriausiai, būtų rimto karinio konflikto, kai jau naudojami branduoliniai ginklai, metu.

Spalio 26 d. NGVC pražaidžia trečiosios „Zapad operacijos“ dalies kulminaciją, t. y. jos pati blogiausią variantą, kai konfrontuojančios šalys apsikeičia masiniais branduoliniais smūgiais. Pagal Rusijos įstatymus tik Prezidentas gali inicijuoti masinį branduolinị atsaką. Tą dieną kaip tik vyksta Rusijos nacionalinio saugumo tarybos poseddis ${ }^{178}$, tad, pasibaigus jam, visi šios tarybos nariai vyksta į NGVS, kur, susipažinę su situacija, priima sprendimą masiniam smūgiui. Visa branduolinè triada suduoda koordinuotą masinị branduolinị smūgị. Balistinė raketa iš Plesecko, trys iš povandeninių laivų paleistos raketos ir keletas iš strateginių bombonešių paleistų sparnuotųjų raketų sèkmingai pasiekia taikinius, esančius už tūkstančių kilometrų ${ }^{179}{ }^{180}$. Oficialiai pranešama, kad Putinas, kaip vyriausias ginkluotųjų pajėgų vadas, pats duoda ịsakymą jas paleisti ${ }^{181}$. „Zapad operacijos“ tikrinimas baigtas. Kitą dieną Gynybos ministerijoje ìvyksta kolegijos posėdis, kuriame S. Šoigu paskelbia, kad Zapad kelti tikslai buvo pasiekti ${ }^{182}$. Rusija ne tik patikrina visą etapą iki galo, bet taip pat pasiunčia Vakarams žinią apie pasirengimą "peržengti Rubikoną“, t. y. masiškai panaudoti branduolinius ginklus. Ar tai taps kasmetine Rusijos praktika, atsakant į JAV vykdomus kasmetinius branduolinès triados mokymus „Globalus Griausmas" (ang. Global Thunder) ${ }^{183}$, parodys laikas.

Apibendrinant trečiojo etapo i̇vykius, matome, kad veiksmų pobū-

\footnotetext{
${ }^{176}$ „В России эвакуировали уже более миллиона человек в связи с „минированиями“, Москва, РИА Новости, 2017-10-10.

${ }^{177}$ А. Карапетян, „В РФ почти 1,4 миллиона человек эвакуировали с начала волны „минирований“, Москва, РИА Новости, 2017-10-26.

${ }^{178}$ RTR, žinios „Vesti“, 19.00, 2017-10-26.

179 „Минобороны провело тренировку по управлению Стратегическими ядерными силами“, Москва, РИА Новости, 2017-10-26.

180 „В рамках учений РВСН с Плесецка запущена МБР „Тополь“ - Минобороны РФ“, Москва, Интерфакс-АВН, 2017-10-26.

${ }^{181}$ „Путин на учениях в четверг запустил четыре баллистические ракеты“, Москва, РИА Новости, 2017-10-26.

182 А. Тихонов, „Факторы роста обороноспособности“, Красная звезда, 2017-10-29, http://www. redstar.ru/index.php/newspaper/item/34943-faktory-rosta-oboronosposobnosti.

${ }^{183}$ Kasmetiniai JAV branduolinès triados mokymai „Global Thunder 2018 “ prasidejo lapkričio $30 \mathrm{~d}$.
} 
dis pasikeite iš esmès. Ankstesniuose etapuose dominavusị puolimą pakeitė plataus masto gynyba, masiškai panaudojant konvencines pajégas ir pereinant i kontrpuolimus ten, kur susidare palanki situacija. Gynyba mažiau remiama iš oro ir didelio nuotolio tikslaus nutaikymo ginklais, tačiau panaudojamas strateginis branduolinis ginklas, dèl ko ruošiamasi sulaukti ir atsako. I veiksmus ìvairiais pretekstais įtraukiamos kitos struktūros (Nacionalinè gvardija ir t. t.). Trečiajame etape (žr. 3 lentelę), neskaičiuojant kitų institucijų karių, galèjo dalyvauti daugiau nei 27 tūkst. karių, apie 2000 vnt. kovos ir kitos karinès technikos ir įrangos, apie 130 orlaivių ir apie 50 laivų. Kiek kitų struktūrų karių buvo itraukta, galima tik spèlioti, o ar skaičiuoti evakuojamus civilius, kaip mokymų dalyvius, yra diskutuotina.

3 lentelè. Zapad-17, tikètina, 3-asis etapas „Visuotinè gynyba“

\begin{tabular}{|c|c|c|c|c|c|}
\hline $\begin{array}{l}\text { Data } \\
2017\end{array}$ & $\begin{array}{l}\text { Jungtinè } \\
\text { strateginè } \\
\text { vadovybė } \\
\text { JSV }\end{array}$ & Vienetai/Vieta & Dydis* & Veikla & Pastabos \\
\hline $\begin{array}{l}\text { Rugsèjo } \\
12 \mathrm{~d} .\end{array}$ & $\begin{array}{l}\text { JSV } \\
\text { branduolinès } \\
\text { pajègos }\end{array}$ & $\begin{array}{l}\text { Strateginių } \\
\text { rakety OV }\end{array}$ & $\begin{array}{l}? \\
1 \text { balistinè } \\
\text { raketa }\end{array}$ & $\begin{array}{l}\text { Puolimas, gy- } \\
\text { nyba. Balistinès } \\
\text { raketos paleidi- } \\
\text { mas }\end{array}$ & $\begin{array}{l}\text { Oficialiai - ne } \\
\text { Zapad, veiksmų } \\
\text { sinchronizacija ir } \\
\text { pobūdis }\end{array}$ \\
\hline $\begin{array}{l}\text { Rugsèjo } \\
13-? \text { d. }\end{array}$ & $\begin{array}{l}\text { JSV „Va- } \\
\text { karai“" }\end{array}$ & $\begin{array}{l}\text { Ryšių vienetai } \\
\text { Kaliningrado } \\
\text { sritis }\end{array}$ & $\begin{array}{l}+-400 \mathrm{~K} \\
+-30 \mathrm{KT}\end{array}$ & $\begin{array}{l}\text { Sukuria ir išlaiko } \\
\text { V2R tinklą }\end{array}$ & $\begin{array}{l}\text { Oficialiai - ne } \\
\text { Zapad, veiksmų } \\
\text { sinchronizacija ir } \\
\text { pobūdis }\end{array}$ \\
\hline $\begin{array}{l}\text { Rugsèjo } \\
13 \mathrm{~d} .\end{array}$ & $\begin{array}{l}\text { JSV „Va- } \\
\text { karai“ }\end{array}$ & $\begin{array}{l}\text { 11-asis } \\
\text { korp., 79-oji } \\
\text { motošauliu brig., } \\
\text { 7-asis MP }\end{array}$ & $\begin{array}{l}+-1000 \mathrm{~K} \\
+-100 \mathrm{KT} \\
+-4 \mathrm{Ai} . \text { ir Sr. }\end{array}$ & $\begin{array}{l}\text { Gynyba, } \\
\text { puolimas. Gy- } \\
\text { nyba, pereinant i } \\
\text { kontrpuolimą }\end{array}$ & $\begin{array}{l}\text { Oficialiai - ne } \\
\text { Zapad, veiksmų } \\
\text { sinchronizacija ir } \\
\text { pobūdis }\end{array}$ \\
\hline $\begin{array}{l}\text { Rugsèjo } \\
13 \mathrm{~d} .\end{array}$ & $\begin{array}{l}\text { JSV „Va- } \\
\text { karai““ }\end{array}$ & $\begin{array}{l}\text { Specialiujų } \\
\text { pajejgu vienetai } \\
\text { Tambovo sritis }\end{array}$ & $?$ & $\begin{array}{l}\text { Gynyba, } \\
\text { puolimas. } \\
\text { Reidai priešo } \\
\text { užnugaryje, } \\
\text { žvalgyba }\end{array}$ & $\begin{array}{l}\text { Oficialiai - ne } \\
\text { Zapad, veiksmų } \\
\text { sinchronizacija ir } \\
\text { pobūdis }\end{array}$ \\
\hline $\begin{array}{l}\text { Rugsèjo } \\
14 \mathrm{~d} .\end{array}$ & $\begin{array}{l}\text { JSV „Va- } \\
\text { karai“ }\end{array}$ & $\begin{array}{l}\text { 11-asis korp. Oro } \\
\text { gynybos vienetai }\end{array}$ & $\begin{array}{l}+-100 \mathrm{~K} \\
+-10 \mathrm{O}\end{array}$ & $\begin{array}{l}\text { Gynyba. Oro } \\
\text { erdvès gynyba }\end{array}$ & Oficialus Zapad \\
\hline $\begin{array}{l}\text { Rugsèjo } \\
14 \mathrm{~d} .\end{array}$ & $\begin{array}{l}\text { JSV „Va- } \\
\text { karai“, } \\
\text { branduolinès } \\
\text { pajègos }\end{array}$ & $\begin{array}{l}\text { 6-oji Oro OV } \\
\text { Strateginès } \\
\text { aviacijos OV }\end{array}$ & $\begin{array}{l}+-? 00 \mathrm{~K} \\
+-20 \mathrm{O}\end{array}$ & $\begin{array}{l}\text { Gynyba, } \\
\text { puolimas. Oro } \\
\text { kontrsmūgis }\end{array}$ & Oficialus Zapad \\
\hline $\begin{array}{l}\text { Rugsèjo } \\
14 \mathrm{~d} .\end{array}$ & $\begin{array}{l}\text { JSV oro- } \\
\text { kosmoso } \\
\text { pajėgos }\end{array}$ & $\begin{array}{l}\text { Baltijos laivyno } \\
\text { oro gynybos } \\
\text { vienetai }\end{array}$ & $\begin{array}{l}+-500 \mathrm{~K} \\
+-50 \mathrm{KT} \\
7 \mathrm{LA}\end{array}$ & $\begin{array}{l}\text { Gynyba. Oro } \\
\text { gynyba, orlaiviai } \\
\text { S300, S400 }\end{array}$ & Oficialus Zapad \\
\hline $\begin{array}{l}\text { Rugsèjo } \\
14-20 \mathrm{~d} .\end{array}$ & $\begin{array}{l}\text { JSV „Va- } \\
\text { karai“ }\end{array}$ & $\begin{array}{l}\text { 1-oji tankų OV } \\
\text { 4-oji TD 6-oji } \\
\text { tankų brig. } \\
\text { Baltarusija }\end{array}$ & $\begin{array}{l}+-3000 \mathrm{~K} \\
+-300 \mathrm{KT}\end{array}$ & $\begin{array}{l}\text { Gynyba, puoli- } \\
\text { mas. Gynybos } \\
\text { stiprinimas, } \\
\text { gynyba, kontrpu- } \\
\text { olimas }\end{array}$ & Oficialus Zapad \\
\hline
\end{tabular}




\begin{tabular}{|c|c|c|c|c|c|}
\hline $\begin{array}{l}\text { Rugsėjo } \\
14-20 \mathrm{~d} .\end{array}$ & $\begin{array}{l}\text { JSV „Va- } \\
\text { karai““ }\end{array}$ & $\begin{array}{l}\text { Rusijos-Bal- } \\
\text { tarusijos karinè } \\
\text { grupuotė } \\
\text { Baltarusija }\end{array}$ & $\begin{array}{l}\text {-+10000 K } \\
\text { +-300 KT } \\
\text { +-50 Lek. ir Sr. }\end{array}$ & $\begin{array}{l}\text { Gynyba, puoli- } \\
\text { mas. Gynybos sti- } \\
\text { prinimas, gynyba, } \\
\text { kontrpuolimas }\end{array}$ & Oficialus Zapad \\
\hline $\begin{array}{l}\text { Rugsèjo } \\
14-18 \mathrm{~d} .\end{array}$ & JSV „Šiaurè“ & Šiaurès laivynas & $\begin{array}{l}+-5000 \mathrm{~K} \\
+-300 \mathrm{KT} \\
+-30 \mathrm{O} \\
+-20 \mathrm{LA} 10 \mathrm{PL}, \\
30 \mathrm{KL}\end{array}$ & $\begin{array}{l}\text { Gynyba. Laivai } \\
\text { išplaukia i } \\
\text { atsarginius } \\
\text { rajonus. }\end{array}$ & $\begin{array}{l}\text { Oficialiai - ne } \\
\text { Zapad, veiksmų } \\
\text { sinchronizacija ir } \\
\text { pobūdis }\end{array}$ \\
\hline $\begin{array}{l}\text { Rugsẻjo } \\
14 \mathrm{~d} .\end{array}$ & $\begin{array}{l}\text { JSV greitojo } \\
\text { reagavimo } \\
\text { pajėgos }\end{array}$ & $\begin{array}{l}76-o j i, 106-o j i, \\
98-o j i ~ D D\end{array}$ & $?$ & $\begin{array}{l}\text { Gynyba, puoli- } \\
\text { mas. Gynybos } \\
\text { stiprinimas, } \\
\text { kontrpuolimas }\end{array}$ & Oficialus Zapad \\
\hline $\begin{array}{l}\text { Rugsėjo } \\
14 \mathrm{~d} .\end{array}$ & JSV „Pietūs“ & $\begin{array}{l}\text { Juodosios jūros } \\
\text { laivynas } \\
\text { Sirija }\end{array}$ & $\begin{array}{l}+-100 \mathrm{~K} \\
2 \mathrm{PL}\end{array}$ & $\begin{array}{l}\text { Gynyba. } \\
\text { Sparnuotujų } \\
\text { raketų paleidimas }\end{array}$ & $\begin{array}{l}\text { Oficialiai - ne } \\
\text { Zapad, veiksmų } \\
\text { sinchronizacija ir } \\
\text { pobūdis }\end{array}$ \\
\hline $\begin{array}{l}\text { Rugsèjo } \\
15 \mathrm{~d} .\end{array}$ & $\begin{array}{l}\text { JSV „Va- } \\
\text { karai“ }\end{array}$ & $\begin{array}{l}\text { Baltijos laivynas, } \\
\text { Jūrų spec. } \\
\text { pajėgos } \\
\text { Kaliningradas }\end{array}$ & $\begin{array}{l}+-50 K \\
+-2 L A\end{array}$ & $\begin{array}{l}\text { Gynyba. Kova su } \\
\text { priešo koviniais } \\
\text { narais, laivų } \\
\text { apsauga }\end{array}$ & Oficialus Zapad \\
\hline $\begin{array}{l}\text { Rugsėjo } \\
15 \mathrm{~d} .\end{array}$ & $\begin{array}{l}\text { JSV „Va- } \\
\text { karai“ }\end{array}$ & $\begin{array}{l}\text { 11-asis korp. } \\
\text { 79-oji motošauliụ } \\
\text { brig., 7-asis MP }\end{array}$ & $\begin{array}{l}+-000 \mathrm{~K} \\
\text { ? ? KT }\end{array}$ & $\begin{array}{l}\text { Gynyba, puoli- } \\
\text { mas. Gynyba, } \\
\text { kontratakos }\end{array}$ & Oficialus Zapad \\
\hline $\begin{array}{l}\text { Rugsèjo } \\
15 \mathrm{~d} .\end{array}$ & $\begin{array}{l}\text { JSV „Va- } \\
\text { karai“ }\end{array}$ & $\begin{array}{l}\text { 6-oji oro OV } \\
\text { Baltijos laivyno } \\
\text { aviacija } \\
\text { Baltijos laivyno } \\
\text { Oro gynybos } \\
\text { pajègos }\end{array}$ & $\begin{array}{l}+-200 \mathrm{~K} \\
20 \mathrm{O}\end{array}$ & $\begin{array}{l}\text { Gynyba. Oro } \\
\text { gynyba }\end{array}$ & Oficialus Zapad \\
\hline $\begin{array}{l}\text { Rugsẻjo } \\
15 \mathrm{~d} .\end{array}$ & $\begin{array}{l}\text { JSV „Va- } \\
\text { karai“ }\end{array}$ & $\begin{array}{l}\text { JSV ABC } \\
\text { vienetai } \\
\text { Luga }\end{array}$ & $\begin{array}{l}+-100 \mathrm{~K} \\
\mathrm{X} ? \mathrm{KT}\end{array}$ & $\begin{array}{l}\text { Gynyba, } \\
\text { puolimas. Savo } \\
\text { pajėgu aerozo- } \\
\text { linis kamufliažas }\end{array}$ & Oficialus Zapad \\
\hline $\begin{array}{l}\text { Rugsèjo } \\
15 \mathrm{~d} .\end{array}$ & $\begin{array}{l}\text { JSV „Va- } \\
\text { karai“" }\end{array}$ & $\begin{array}{l}\text { Elektroninès } \\
\text { kovos vienetai } \\
\text { Luga }\end{array}$ & $?$ & $\begin{array}{l}\text { Gynyba. Savo } \\
\text { pajėgų prie- } \\
\text { danga nuo oro } \\
\text { antskrydžių }\end{array}$ & Oficialus Zapad \\
\hline $\begin{array}{l}\text { Rugsèjo } \\
15 \mathrm{~d} .\end{array}$ & $\begin{array}{l}\text { JSV „Va- } \\
\text { karai“ }\end{array}$ & Ryšių vienetai & $?$ & $\begin{array}{l}\text { Gynyba. „Cyber" } \\
\text { atakų prieš savo } \\
\text { „Vdefense“, CR } \\
\text { atrèmimas }\end{array}$ & Oficialus Zapad \\
\hline $\begin{array}{l}\text { Rugsèjo } \\
16 \mathrm{~d} .\end{array}$ & $\begin{array}{l}\text { JSV „Va- } \\
\text { karai“ }\end{array}$ & 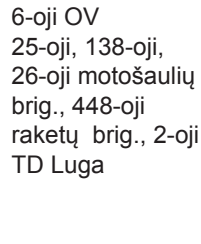 & $\begin{array}{l}+-1500 \mathrm{~K} \\
+-300 \mathrm{KT} \\
+-300\end{array}$ & $\begin{array}{l}\text { Gynyba, } \\
\text { puolimas. Gy- } \\
\text { nyba, perèjimas } \\
\text { i kontrataką, } \\
\text { parama „Is- } \\
\text { kander“ ir „Točka } \\
\text { U“ balistinèmis } \\
\text { raketomis }\end{array}$ & Oficialus Zapad \\
\hline $\begin{array}{l}\text { Rugsèjo } \\
15 \mathrm{~d} .\end{array}$ & $\begin{array}{l}\text { JSV „Va- } \\
\text { karai“ }\end{array}$ & $\begin{array}{l}\text { JSV logistikos } \\
\text { vienetai } \\
\text { Luga }\end{array}$ & $\begin{array}{l}? 00 \mathrm{~K} \\
+-100 \mathrm{KT}\end{array}$ & $\begin{array}{l}\text { Gynyba } \\
\text { Pažeistos tech- } \\
\text { nikos evakavimas } \\
\text { ir atstatymas }\end{array}$ & Oficialus Zapad \\
\hline
\end{tabular}




\begin{tabular}{|c|c|c|c|c|c|}
\hline $\begin{array}{l}\text { Rugsėjo } \\
14-18 \mathrm{~d} .\end{array}$ & $\begin{array}{l}\text { JSV „Va- } \\
\text { karai“ }\end{array}$ & Šiaurès laivynas & $\begin{array}{l}+-5000 \mathrm{~K} \\
+-300 \mathrm{KT} \\
+-30 \mathrm{O} \\
+-20 \mathrm{LA} \\
10 \mathrm{PL}, 30 \mathrm{KL}\end{array}$ & $\begin{array}{l}\text { Gynyba. } \\
\text { Priešlaivinè ir oro } \\
\text { gynyba jūroje, } \\
\text { artileriniai ir ra- } \\
\text { ketiniai šaudymai }\end{array}$ & $\begin{array}{l}\text { Oficialiai - ne } \\
\text { Zapad, veiksmų } \\
\text { sinchronizacija ir } \\
\text { pobūdis }\end{array}$ \\
\hline $\begin{array}{l}\text { Rugsèjo } \\
15 \mathrm{~d} .\end{array}$ & $\begin{array}{l}\text { JSV „Va- } \\
\text { karai““ }\end{array}$ & $\begin{array}{l}\text { Sausumos } \\
\text { pajėgu vienetai } \\
\text { Pečenga }\end{array}$ & $\begin{array}{l}+-150 \mathrm{KS} \\
+-300 \mathrm{KT}\end{array}$ & $\begin{array}{l}\text { Gynyba. Krantų } \\
\text { gynyba nuo jūrų } \\
\text { desanto }\end{array}$ & $\begin{array}{l}\text { Oficialiai - ne } \\
\text { Zapad, veiksmų } \\
\text { sinchronizacija ir } \\
\text { pobūdis }\end{array}$ \\
\hline $\begin{array}{l}\text { Rugsèjo } \\
15 \mathrm{~d} .\end{array}$ & $\begin{array}{l}\text { JSV bran- } \\
\text { duolines } \\
\text { pajègos }\end{array}$ & $\begin{array}{l}\text { Strateginès } \\
\text { aviacijos OV }\end{array}$ & $\begin{array}{l}? \\
10\end{array}$ & $\begin{array}{l}\text { Gynyba, puoli- } \\
\text { mas. Strateginis } \\
\text { patruliavimas, } \\
\text { avarija }\end{array}$ & $\begin{array}{l}\text { Oficialiai - ne } \\
\text { Zapad, veiksmų } \\
\text { sinchronizacija ir } \\
\text { pobūdis }\end{array}$ \\
\hline $\begin{array}{l}\text { Rugsėjo } \\
15-17 \mathrm{~d} .\end{array}$ & $\begin{array}{l}\text { JSV „Va- } \\
\text { karai““ }\end{array}$ & $\begin{array}{l}\text { Baltijos laivynas } \\
25-0 j i \text { krantų } \\
\text { gynybos brig. }\end{array}$ & $\begin{array}{l}? 000 \mathrm{~K} \\
20 \mathrm{~L}\end{array}$ & $\begin{array}{l}\text { Gynyba. } \\
\text { Priešlaivinè } \\
\text { ir oro gynyba } \\
\text { jūroje, artiler- } \\
\text { iniai šaudymai, } \\
\text { krantų gynybos, } \\
\text { "Bal“, „Bastion“ } \\
\text { šaudymai }\end{array}$ & Oficialus Zapad \\
\hline $\begin{array}{l}\text { Rugsèjo } \\
15 \mathrm{~d} .\end{array}$ & $\begin{array}{l}\text { JSV greitojo } \\
\text { reagavimo } \\
\text { pajėgos }\end{array}$ & 108-oji DD & $\begin{array}{l}+-500 \mathrm{~K} \\
+-10 \mathrm{KT}\end{array}$ & $\begin{array}{l}\text { Gynyba, puolimas. } \\
\text { Reidai priešo } \\
\text { užnugaryje }\end{array}$ & Oficialus Zapad \\
\hline $\begin{array}{l}\text { Rugsėjo } \\
15-18 \mathrm{~d} .\end{array}$ & $\begin{array}{l}\text { JSV „Va- } \\
\text { karai““ }\end{array}$ & $\begin{array}{l}\text { 1-oji tankü } \\
\text { OV, 2-oji MD, } \\
\text { 138-oji ir 25-oji } \\
\text { motošauliụ brig., } \\
\text { kiti vienetai, } \\
\text { Luga }\end{array}$ & $\begin{array}{l}+-1500 \mathrm{~K} \\
+-300 \mathrm{KT} \\
+-10 \mathrm{O} \text { ir Sr. }\end{array}$ & $\begin{array}{l}\text { Gynyba, puoli- } \\
\text { mas. Artilerija } \\
\text { stabdo atakas, } \\
\text { kontratakos }\end{array}$ & Oficialus Zapad \\
\hline $\begin{array}{l}\text { Rugsèjo } \\
16 \mathrm{~d} .\end{array}$ & $\begin{array}{l}\text { JSV „Va- } \\
\text { karai““ }\end{array}$ & $\begin{array}{l}\text { 6-oji oro OV } \\
\text { Leningrado, Ka- } \\
\text { liningrado sritys }\end{array}$ & $\begin{array}{l}+-100 \mathrm{~K} \\
+-10 \mathrm{O}\end{array}$ & $\begin{array}{l}\text { Gynyba, puoli- } \\
\text { mas. Dvišaliai } \\
\text { oro gynybos ir } \\
\text { paramos iš oro } \\
\text { mokymai }\end{array}$ & Oficialus Zapad \\
\hline $\begin{array}{l}\text { Rugsèjo } \\
16 \mathrm{~d} .\end{array}$ & $\begin{array}{l}\text { JSV „Va- } \\
\text { karai““ }\end{array}$ & $\begin{array}{l}\text { JSV „Vakarai“ lo- } \\
\text { gistikos vienetai } \\
\text { Baltarusija }\end{array}$ & $?$ & $\begin{array}{l}\text { Gynyba. } \\
\text { Pažeistos tech- } \\
\text { nikos evakavi- } \\
\text { mas ir atstaty- } \\
\text { mas, logistinis } \\
\text { aprūpinimas }\end{array}$ & Oficialus Zapad \\
\hline $\begin{array}{l}\text { Rugsèjo } \\
16-18 \text { d. }\end{array}$ & $\begin{array}{l}\text { JSV „Va- } \\
\text { karai““ }\end{array}$ & $\begin{array}{l}\text { 6-oji oro OV, } \\
\text { Aviacijos vienetai } \\
\text { Luga }\end{array}$ & $\begin{array}{l}\text { X? K } \\
+-10 \mathrm{Sr} .\end{array}$ & $\begin{array}{l}\text { Gynyba, puoli- } \\
\text { mas. } \\
\text { Sraigtasparnių } \\
\text { pasalos, parama } \\
\text { iš oro }\end{array}$ & Oficialus Zapad \\
\hline $\begin{array}{l}\text { Rugsèjo } \\
17-20 \text { d. }\end{array}$ & $\begin{array}{l}\text { JSV „Va- } \\
\text { karai“ }\end{array}$ & $\begin{array}{l}\text { 1-oji tankų OV, } \\
\text { 4-oji TD, 6-oji } \\
\text { tankų brig. Bal- } \\
\text { tarusija }\end{array}$ & $\begin{array}{l}+-3500 \mathrm{~K} \\
+-500 \mathrm{KT} \\
\geq 10 \mathrm{O} \text { ir Sr. }\end{array}$ & $\begin{array}{l}\text { Gynyba, puoli- } \\
\text { mas. Gynyba } \\
\text { ir perëjimas i } \\
\text { kontrpuolimą }\end{array}$ & Oficialus Zapad \\
\hline $\begin{array}{l}\text { Rugsèjo } \\
17-20 \mathrm{~d} .\end{array}$ & $\begin{array}{l}\text { JSV „Va- } \\
\text { karai“ }\end{array}$ & $\begin{array}{l}\text { JSV „Vakarai“ lo- } \\
\text { gistikos pajėgos } \\
\text { Luga }\end{array}$ & $\begin{array}{l}+-? 00 \mathrm{~K} \\
+-30 \mathrm{KT}\end{array}$ & $\begin{array}{l}\text { Gynyba. Logis- } \\
\text { tinis aprūpinimas, } \\
\text { vandenvala }\end{array}$ & Oficialus Zapad \\
\hline $\begin{array}{l}\text { Rugsèjo } \\
18 \mathrm{~d} .\end{array}$ & $\begin{array}{l}\text { JSV greitojo } \\
\text { reagavimo } \\
\text { pajėgos }\end{array}$ & $\begin{array}{l}\text { JBr. } \\
\text { Pumanki, Mur- } \\
\text { mansko sritis }\end{array}$ & $\begin{array}{l}+-600 \mathrm{~K} \\
\text { ? KT }\end{array}$ & $\begin{array}{l}\text { Gynyba. Kranto } \\
\text { gynyba nuo jūros } \\
\text { desanto }\end{array}$ & Oficialus Zapad \\
\hline
\end{tabular}




\begin{tabular}{|c|c|c|c|c|c|}
\hline $\begin{array}{l}\text { Rugsèjo } \\
19 \mathrm{~d} .\end{array}$ & $\begin{array}{l}\text { JSV greitojo } \\
\text { reagavimo } \\
\text { pajėgos }\end{array}$ & 76-oji DD & $\begin{array}{l}+-500 \mathrm{~K} \\
+-10 \mathrm{KT} \\
6 \mathrm{O}\end{array}$ & $\begin{array}{l}\text { Puolimas. Kon- } \\
\text { trpuolimas ir oro } \\
\text { uosto užgrobimas }\end{array}$ & Oficialus Zapad \\
\hline $\begin{array}{l}\text { Rugsèjo } \\
20 \text { d. }\end{array}$ & $\begin{array}{l}\text { JSV „Va- } \\
\text { karai“ }\end{array}$ & Baltijos laivynas & $\begin{array}{l}+-1000 \mathrm{~K} \\
+-\geq 20 \mathrm{LA} \\
X ? \mathrm{Sr}\end{array}$ & $\begin{array}{l}\text { Gynyba, puoli- } \\
\text { mas. Gynyba } \\
\text { nuo jūru ir oro } \\
\text { puolimo, kon- } \\
\text { trpuolimas, jūros } \\
\text { desantas }\end{array}$ & Oficialus Zapad \\
\hline $\begin{array}{l}\text { Rugsèjo } \\
14-20 \text { d. }\end{array}$ & $\begin{array}{l}\text { JSV „Va- } \\
\text { karai“ }\end{array}$ & $\begin{array}{l}\text { Topografijos } \\
\text { vienetai }\end{array}$ & $\begin{array}{l}+-250 \mathrm{~K} \\
+-30 \mathrm{KT}\end{array}$ & $\begin{array}{l}\text { Gynyba, puoli- } \\
\text { mas. Navigacinès } \\
\text { sistemos kali- } \\
\text { bravimas }\end{array}$ & Oficialus Zapad \\
\hline $\begin{array}{l}\text { Rugsèjo } \\
19-21 \mathrm{~d} .\end{array}$ & $\begin{array}{l}\text { JSV } \\
\text { branduolinès } \\
\text { pajègos }\end{array}$ & $\begin{array}{l}\text { Strateginès } \\
\text { paskirties raketu, } \\
\text { strateginès } \\
\text { aviacijos OV }\end{array}$ & $\begin{array}{l}? \\
1 \text { balistinè } \\
\text { raketa }\end{array}$ & $\begin{array}{l}\text { Gynyba, } \\
\text { puolimas. Bran- } \\
\text { duolinis smūgis, } \\
\text { oficialiai - } \\
\text { balistinès raketos } \\
\text { bandymas }\end{array}$ & $\begin{array}{l}\text { Oficialiai - ne } \\
\text { Zapad, veiksmų } \\
\text { sinchronizacija ir } \\
\text { pobūdis }\end{array}$ \\
\hline $\begin{array}{l}\text { Spalio } \\
26 \mathrm{~d} .\end{array}$ & $\begin{array}{l}\text { JSV } \\
\text { branduolinès } \\
\text { pajègos }\end{array}$ & $\begin{array}{l}\text { Strateginès } \\
\text { paskirties raketų, } \\
\text { strateginių } \\
\text { povandeninių } \\
\text { laivų ir } \\
\text { strateginès } \\
\text { aviacijos OV }\end{array}$ & $\begin{array}{l}4 \text { balistinès, } \\
\text { X sparnuotų } \\
\text { raketų }\end{array}$ & $\begin{array}{l}\text { Gynyba, puoli- } \\
\text { mas. Masinis } \\
\text { branduolinis } \\
\text { smūgis, oficial- } \\
\text { iai - jungtinių } \\
\text { branduolinių } \\
\text { pajègų treniruotè }\end{array}$ & $\begin{array}{l}\text { Oficialiai - ne } \\
\text { Zapad, veiksmų } \\
\text { sinchronizacija ir } \\
\text { pobūdis }\end{array}$ \\
\hline $\begin{array}{l}\text { Rugsèjo } \\
10 \mathrm{~d} . \\
\text { Spalio } \\
26 \mathrm{~d} .\end{array}$ & $\begin{array}{l}\text { Rusijos } \\
\text { nacionalinè } \\
\text { gvardija, } \\
\text { kitos } \\
\text { struktūros }\end{array}$ & $?$ & $? 0000$ & $\begin{array}{l}\text { Gynyba. Masinè } \\
\text { evakuacija }\end{array}$ & $\begin{array}{l}\text { OFICIALIAI } \\
\text { PRANEŠTA, KAD } \\
\text { TAI - NE PRATY- } \\
\text { BOS }\end{array}$ \\
\hline IŠ VISO: & & & $\begin{array}{l}-+27000 \mathrm{~K} \\
+-2000 \mathrm{KT} \\
-+130 \mathrm{O} \\
50 \mathrm{~L}\end{array}$ & & \\
\hline
\end{tabular}

*Visi skaičiai yra iš atviru šaltiniu arba išskaičiuoti. I galima tų pačiu karių dalyvavima skirtinguose veiksmuose atsižvelgta.

Legenda. JSV - jungtinè strateginè vadovybè, OV - operacinè vadovybè, brig. - brigada, MP - motošaulių pulkas, MD - motošaulių divizija, TD - tankų divizija, DD - oro desanto divizija, JBr. - jūrų pėstininkų brigada, KGbr. - krantų gynybos brigada, $\mathrm{K}$ - kariai/jūreiviai, KT - karine technika (kovos ir kt.), L - laivai: LA - antvandeniniai laivai, PL - povandeniniai laivai, KL - kiti laivai, O - orlaiviai, Lek. - lèktuvai, Sr. - sraigtasparniai.

\section{Išvados}

Rusija ir toliau linkusi laikytis detalaus karinių operacijų planavimo principu. Tai reiškia, kad bet kuriai karinei veiklai, taip pat ir karui su oponentu Vakaruose, ji turi pasirengusi pakankamai detalius veiksmų planus, kuriuos reguliariai tikrina ir atnaujina. Labai panašu, kad, rengiant karo su oponentu 
Vakaruose planus, remiamasi prielaidomis, kad karinių pajègų panaudojimas bus rezultatyvus tik veikiant greitai, efektyviai ir gebant užtvirtinti pasiekimus. Reikia padaryti priešininkui tokius nuostolius, kad jis būtų priverstas derètis. Prištinos operacija Kosove, Zapad-99, Zapad-09 mokymai turbūt ịtikino Rusiją, kad Vakarai nèra linkę veikti ryžtingai, todèl galima laimèti laiko pasirengti naujiems veiksmams arba visuotinei gynybai. Gruzijos 2008 m., Krymo 2014 m. atvejai leidžia Rusijai tikèti, kad, pradejus derybas Vakaruose, bus galima ịtvirtinti tai, kas buvo pasiekta karinėmis priemonemis.

Panašu, kad Rusija mano, kad detalaus planavimo principai gali būti sèkmingai taikomi šiuolaikiniuose karuose. Pagrindinès silpnosios tokio planavimo pusès, išryškejusios praeityje, buvo dvi. Pirma, daugybės situaciju, kurios gali kilti operacijos metu, numatymas reikalavo milžiniško štabų darbo, todèl daug situacijų likdavo neịvertintos. Antra, informacijos rinkimo, situacijos vertinimo ir nurodymų perdavimo laikas buvo ilgas, todèl reagavimas $\mathfrak{i}$ pasikeitimus buvo letas ir didesnio situacijos neatitikimo suplanuotajai atveju planas galèjo žlugti. Panašu, kad Rusijos kariškiai mano, kad šiuolaikinès technologijos leidžia abu šiuos trūkumus pašalinti. Kompiuterių atsiradimas ir NGVC turimi kompiuteriniai pajègumai leidžia sumodeliuoti kiek tik nori situacijų ir jų kombinacijų, todèl galima parengti/ịvertinti praktiškai visas situacijas. Šalia to, dèl technologinio progreso ryšių, stebẻjimo, îvertinimo priemonès leidžia sukurti visaapimantị V2RI tinklą, automatizuotas valdymo sistemas ir t. t., dèl ko galima ne tik greitai pakoreguoti veiksmų eigą, pritaikant iš anksto suplanuotus sprendimus, bet ir praktiškai be uždelsimo perduoti visus nurodymus pajegoms kovos lauke. Iš anksto parengtų ir pakankamai lanksčiai koreguojamų planų turẻjimas sudaro galimybes atitinkamose situacijose veikti greičiau, efektyviau ir taip pasiekti norimus rezultatus. Veikiantys pagal planą gali koncentruotis tik $\mathfrak{i}$ greitą ir maksimalų gaunamų nurodymų ígyvendinimą ir laisvai daro pakeitimus tik taktiniame lygmenyje, o oponentas yra priverstas "gaišti“ laiką tam, kad parengtų atsaką ir jị sukoordinuotų visuose lygmenyse.

Remiantis nuo 1999 m. vykusių Zapad mokymų analize, galima teigti, kad karo su oponentu Vakaruose planas - „Zapad operacija“ - tikriausiai numato tris etapus. Sèkmès atveju jis užbaigiamas po dviejų etapų, nesėkmès - vykdomi visi trys. Nuo 1999 m. Rusija per Zapad mokymus tikrino pajègu pasirengimą šiems etapams: iš pradžių daugiausiai teoriškai ir atskirais etapais, o po 2013 m. (pirmos karinès reformos stadijos pabaiga ir S. Šougu paskyrimas) - praktiškai ir kompleksiškai. Mokymuose, vykusiuose po Zapad-13 (VOSTOK-14, CENTR-15 ir KAVKAZ-16), buvo tikrinami atskiri etapų elementai, kurie per Zapad-17 patikrinti kompleksiškai. 
Nors Rusijos karinè vadovybė įvertino Zapad-17 mokymus kaip pasisekusius, bent jau remiantis turima informacija, panašu, kad kai kurie uždaviniai išlieka neiggyvendinti, o tikslai - nepasiekti. Sẻkmingomis galima būtų vertinti visaapimančio V2R kūrimo pastangas, tačiau kalbèti apie jo pavertimą i j siektiną pilnavertę vadovavimo-valdymo-ryšių ir informacijos sistemą (V2RI) - dar anksti. Progresas yra akivaizdus elektroninès kovos, materialinio-techninio aprūpinimo, perginklavimo, didelio nuotolio tikslaus nutaikymo ir perspektyvinių ginkluotès sistemų, navigacijos srityse. Buvo deklaruota, kad Zapad-17 turëjo įvertinti mobilizacinès sistemos (rezervo), teritorinès gynybos ${ }^{184}$, civilinès gynybos ir federalinès valdžios ${ }^{185}$ ịtraukimo, sąveikos tarp kitų institucijų $\iota^{186}$ efektyvumą, tačiau apie sèkmę, mokymams pasibaigus, beveik nekalbèta, todèl tikètina, kad to, kas planuota, nepasiekè.

Panašu, kad Rusija strateginius mokymus laiko ne tik svarbia plano ir pajègų patikrinimo, bet ir strateginès komunikacijos priemone, leidžiančia daryti įtaką esančiai politinei situacijai. Atskirų akcentų sudèliojimas atskiriems oficialiems Zapad mokymams nèra atsitiktinis. Pvz., Zapad-09 metu akcentuotas branduolinis smūgis galètų būti vertinamas kaip karinès strateginès klastos (maskuotès), skirtos laimèti laiko, atvejis, o Zapad-17 atvirumas, demonstruojant pasiryžimą gintis iki paskutinio, - kaip Stratkomo žinutės „nevaryti Rusijos ị kampą" dalis.

Nuo 1999 m. Rusijoje ịvykę pasikeitimai karinëje ir kitose srityse pademonstravo, kad Rusija ne tik deklaruoja savo išskirtinumą, bet ir stengiasi ji realiai sukurti. Karinejje srityje ji išlaiko ir tobulina kitokị nei Vakarų (NATO) valstybèse supratimą apie karinès veiklos vykdymą ir planavimą. Rusijoje jis paremtas Prūsijos generalinio štabo filosofija. Po Antrojo pasaulinio karo Vakaruose (NATO) šios filosofijos karyboje atsisakyta - ji yra primiršta. Rusija tai išnaudoja, todèl dažnai jos elgesys Vakaruose nesuprantamas, o prognozès, parengtos vakarietiškais principais, nepasiteisina.

Trakai, 2017 m. lapkričio $3 d$.

\footnotetext{
${ }^{184}$ Nors ir buvo paskirtas JSV „Vakarai“ 11-osios rezervo vadovybès vadas plk. Jurijus Štondenko (Юрий Штонденко), tačiau mokymų metu aktyvus mobilizacijos/rezervo panaudojimas nefiksuotas.

${ }^{185}$ Nors š. m. sausio 17 d. gynybos ministro S. Šoigu GM vadovybès sueigoje kalbèta apie civilinès valdžios organų dalyvavimą ir Civilinio teritorinès gynybos štabo išskleidimą, tačiau, ar jis buvo mokymų metu, informacijos nera.

${ }^{186}$ RF prezidento 2017-07-29 ịsakas Nr. 345 suteikè Rusgvardijai igaliojimus aktyviai dalyvauti karinejje veikloje. Nežiūrint ị tai, oficialiai Rusgvardijos dalyvavimas Zapad-17 beveik nefiksuotas.
} 